\title{
Differential Transport and Local Translation of Cytoskeletal, Injury-Response, and Neurodegeneration Protein mRNAs in Axons
}

\author{
Dianna Willis, ${ }^{1 \star}$ Ka Wan Li, ${ }^{2 *}$ Jun-Qi Zheng,,${ }^{1}$ Jay H. Chang, ${ }^{4}$ August Smit, ${ }^{2}$ Theresa Kelly, ${ }^{3}$ Tanuja T. Merianda, ${ }^{1}$ \\ James Sylvester, ${ }^{5}$ Jan van Minnen, ${ }^{2}$ and Jeffery L. Twiss ${ }^{1,6}$ \\ ${ }^{1}$ Nemours Biomedical Research, Alfred I. DuPont Hospital for Children, Wilmington, Delaware 19803, ${ }^{2}$ Department of Molecular and Cellular \\ Neurobiology, Faculty of Earth and Life Sciences, Vrije Universiteit, 1081 HV Amsterdam, The Netherlands, ${ }^{3}$ Neuroscience and ${ }^{4}$ Cellular and Molecular \\ Pathology Graduate Programs, University of California Los Angeles, Los Angeles, California 90095, ${ }^{5}$ Nemours Biomedical Research, Jacksonville, Florida \\ 32247, and ${ }^{\circ}$ Department of Biological Sciences, University of Delaware, Newark, Delaware 19716
}

Recent studies have begun to focus on the signals that regulate axonal protein synthesis and the functional significance of localized protein synthesis. However, identification of proteins that are synthesized in mammalian axons has been mainly based on predictions. Here, we used axons purified from cultures of injury-conditioned adult dorsal root ganglion (DRG) neurons and proteomics methodology to identify axonally synthesized proteins. Reverse transcription (RT)-PCR from axonal preparations was used to confirm that the mRNA for each identified protein extended into the DRG axons. Proteins and the encoding mRNAs for the cytoskeletal proteins $\beta$-actin, peripherin, vimentin, $\gamma$-tropomyosin 3 , and cofilin 1 were present in the axonal preparations. In addition to the cytoskeletal elements, several heat shock proteins (HSP27, HSP60, HSP70, grp75, $\alpha$ B crystallin), resident endoplasmic reticulum (ER) proteins (calreticulin, grp78/BiP, ERp29), proteins associated with neurodegenerative diseases (ubiquitin C-terminal hydrolase L1, rat ortholog of human DJ-1/Park7, $\gamma$-synuclein, superoxide dismutase 1), anti-oxidant proteins (peroxiredoxins 1 and 6), and metabolic proteins (e.g., phosphoglycerate kinase 1 (PGK 1), $\alpha$ enolase, aldolase C/Zebrin II) were included among the axonally synthesized proteins. Detection of the mRNAs encoding each of the axonally synthesized proteins identified by mass spectrometry in the axonal compartment indicates that the DRG axons have the potential to synthesize a complex population of proteins. Local treatment of the DRG axons with NGF or BDNF increased levels of cytoskeletal mRNAs into the axonal compartment by twofold to fivefold but had no effect on levels of the other axonal mRNAs studied. Neurotrophins selectively increased transport of $\beta$-actin, peripherin, and vimentin mRNAs from the cell body into the axons rather than changing transcription or mRNA survival in the axonal compartment.

Key words: axonal protein synthesis; mRNA transport; neurotrophin; cytoskeleton; protein trafficking; heat shock protein

\section{Introduction}

Translation of mRNAs in neuronal processes can provide a locally renewable source of proteins at sites that may be thousands of micrometers distance from the neuronal cell body. Localized protein synthesis in dendrites is a well-accepted mechanism that that can be regulated by neurotransmitters and trophic factors

Received July 19, 2004; revised Nov. 29, 2004; accepted Nov. 30, 2004.

This work was supported by grants from the National Institutes of Health and National Center for Research Resources (NS041596 and RR020173) and programmatic funding from the Nemours Foundation (J.L.T. and J.S.). We do not have financial conflict of interest in this work. Bieshia Chang provided technical assistance with metabolic labeling of DRG axons. Yvonne Gouwenberg provided excellent technical support in the electrophoresis experiments, and Roel van der Schors provided assistance with mass spectrometric analyses. Dr. Leslie Krueger provided technical assistance with real-time PCR. We are grateful to Drs. Gary Bassell, Michael Fainzilber, Carolyn Schanen, Kirk Dabney, Ayyappan Rajasekaran, and Norman Karin for constructive criticism on this work and insights into protein function. Anti-TrkA antibody was kindly provided by Dr. Stuart Feinstein (University of California Santa Barbara, Santa Barbara, (A).

${ }^{*}$ D.W. and K.W.L. contributed equally to this work.

Correspondence should be addressed to Dr. Jeffery L. Twiss, Nemours Biomedical Research, Alfred I DuPont Hospital for Children, 1600 Rockland Road, Room H3B-330,Wilmington, DE 19803.E-mail: twiss@medsci.udel.edu. DOl:10.1523/JNEUROSCI.4235-04.2005

Copyright $\odot 2005$ Society for Neuroscience $\quad$ 0270-6474/05/250778-14\$15.00/0
(Steward, 2002). Evidence for protein synthesis in axons was initially provided from studies in invertebrates (Capano et al., 1987; Giuditta et al., 1991; Davis et al., 1992; Chun et al., 1996; van Minnen et al., 1997). Subsequent work showed that developing vertebrate axons contain mRNAs and actively synthesize proteins (Olink-Coux and Hollenbeck, 1996; Bassell et al., 1998; Eng et al., 1999; Zhang et al., 1999; Aronov et al., 2001; Campbell and Holt, 2001; Lee and Hollenbeck, 2003). Several lines of evidence indicate that mammals retain the capacity for axonal protein synthesis as they mature (Koenig et al., 2000; Zheng et al., 2001; Hanz et al., 2003). Functional studies have shown that axonal protein synthesis contributes to turning of growth cones in response to chemotropic agents (Campbell and Holt, 2001; Brittis et al., 2002; Ming et al., 2002) and generation of retrograde signaling complexes (Hanz et al., 2003).

Despite this apparent involvement of axonal protein synthesis in the above mentioned processes, only a few proteins are known to be produced in vertebrate axons. Lee and Hollenbeck (2003) recently estimated that axonal protein synthesis represents $5 \%$ of total neuronal protein synthesis. At present, the list of proteins 
locally synthesized in vertebrate axons is limited to $\beta$-actin, $\alpha$-tubulin, low molecular weight neurofilament, Tau, actindepolymerizing factor (ADF), EphA2, and Importin $\beta 1$ (OlinkCoux and Hollenbeck, 1996; Bassell et al., 1998; Eng et al., 1999; Zheng et al., 2001; Hanz et al., 2003; Lee and Hollenbeck, 2003). Including mRNAs identified in vertebrate axons, such as neurohormones and other neurofilament subunits, approximately doubles the list of proteins that are potentially synthesized in axons (Piper and Holt, 2004). Our previous biochemical analysis of DRG axons, however, suggests that only a fraction of axonally synthesized proteins are represented by these current studies (Zheng et al., 2001). Here, we used proteomics methodologies as a novel means to catalog axonally synthesized proteins from injury-conditioned adult rat dorsal root ganglion (DRG) neurons, which show robust intra-axonal protein synthesis in culture (Zheng et al., 2001). We show that growing DRG axons synthesizes a complex population of proteins. Mass spectrometry (MS) showed that microtubule, intermediate filament and microfilament proteins, several heat shock proteins (HSPs) and heat shock-like proteins, endoplasmic reticulum (ER)-resident chaperone proteins, proteins linked to neurodegenerative disorders including those with proteolytic functions, and metabolic proteins are locally synthesized in axons. Extension of the transcripts encoding each of these proteins into axonal compartment was confirmed by reverse transcription (RT)-PCR. HSP70 and $\alpha \mathrm{B}$ crystallin transcripts appeared enriched in the axons compared with the other axonal mRNAs examined. Locally treating axons with a source of neurotrophins caused a twofold to fivefold increase in axonal levels of $\beta$-actin, vimentin, and peripherin mRNAs. Levels of the other analyzed mRNAs were not altered by neurotrophin treatment, arguing that nerve growth factor (NGF) and brain-derived neurotrophic factor (BDNF) selectively increase transport of cytoskeletal mRNAs into the axonal compartment.

\section{Materials and Methods}

Cell culture. Primary DRG cultures were prepared from adult Sprague Dawley rats that had been "injury conditioned" by sciatic nerve crush at midthigh level $7 \mathrm{~d}$ previously. All animal surgeries and killings were performed under institutional Animal Care and Use Committee guidelines. Dissociated cultures were prepared from L4-6 DRGs as described previously (Twiss et al., 2000). Culture for isolation of axons is described below. For immunolocalization studies, DRGs were cultured at low density on poly-L-lysine/laminin-coated coverslips. Pheochromocytoma 12 (PC12) cells were maintained in DMEM supplemented with $6 \%$ horse and $6 \%$ calf serum (Hyclone, Logon, UT). For treatment with soluble or immobilized NGF (see below), cells were serum starved for $1 \mathrm{~h}$ in DMEM containing $0.1 \%$ bovine serum albumin (BSA; Sigma, St. Louis, MO) (Chang et al., 2003).

Culture method for isolation of axons. Culture method for isolation of DRG axons has been described previously (Zheng et al., 2001). Briefly, dissociated DRGs were plated into tissue culture inserts containing porous membrane ( $8 \mu \mathrm{m}$ pores; BD Falcon, Bedford, MA) coated with poly-L-lysine/laminin. Axons were isolated after $16-20 \mathrm{~h}$ in culture by carefully scraping the cellular contents from the upper membrane surface with a cotton-tipped applicator (four times, alternating the direction by $90^{\circ}$ each time). For isolation of cell-body compartment, the under surface of the membrane was scraped in an identical manner to remove the axons that had penetrated the membrane. For metabolic labeling, the axons were isolated from the cell body after $16 \mathrm{~h}$ in culture. The scraped membranes were excised from the insert and incubated in DMEM/F-12 with $4 \mathrm{mCi} / \mathrm{ml}\left[{ }^{35} \mathrm{~S}\right]$ methionine/cysteine (ICN Biochemicals, Costa Mesa, CA) for $4 \mathrm{~h}$. For RNA extraction, axons were isolated from the cell body after $20 \mathrm{~h}$ in culture.

Immunoblotting. Protein was isolated from cell-body or axonal compartments prepared as above using radioimmunoprecipitation assay
(RIPA) buffer and quantitated by Bradford assay. Protein was resolved on SDS-PAGE gels, transferred to polyvinylidene difluoride (PVDF), and immunoblotted with rabbit anti-Tau antibodies (1:500; Sigma), antityrosine receptor kinase (Trk) ${ }^{\text {P490 }}$ (1:2000; Cell Signaling Technology, Beverly, MA), or Trk (provided by Dr. Stuart Feinstein, University of California Santa Barbara, Santa Barbara, CA) (Molliver et al., 1995). Procedures for blocking, incubation with primary antibodies and chemiluminescent detection of HRP-conjugated secondary antibodies were described previously (Zheng et al., 2001). Standard ECL reagent was used to detect Tau and Trk, and ECL ${ }^{\text {plus }}$ reagent (Amersham Biosciences, Piscataway, NJ) was used to detect phospho-TrkA.

Two-dimensional electrophoretic analyses of axonally synthesized proteins. For two-dimensional (2D) electrophoresis, sheared axons were rinsed three times in warm PBS after metabolic labeling for $4 \mathrm{~h}$ and then lysed in buffer containing the following: $20 \mathrm{~mm}$ Tris, $\mathrm{pH} 7.5,2 \mathrm{M}$ thiourea, $7 \mathrm{~m}$ urea, 4\% 3-[(3-cholamidopropyl)dimethylammonio]-1propanesulfonate, $0.5 \%$ DTT, and $0.5 \%$ Triton X-100. Because the protein amount of the axons was very low, lysates of two unlabeled DRGs were included in these samples as a carrier. Three hundred fifty microliters of the sample were used for the rehydration and simultaneous loading of the proteins to the immobilized $\mathrm{pH}$ gradient (IPG) strip (Amersham Biosciences), which was then focused for $65,000 \mathrm{~V} / \mathrm{h}$. The second dimension was run overnight on $11 \%$ SDS-PAGE. Proteins from the 2D gel were electrotransferred to nitrocellulose and then exposed to a plate for radioisotope imaging and scanned with FLA-5000 (Fuji, Tokyo, Japan). The protein content on the nitrocellulose membrane was revealed by gold staining (Aurodye; Amersham Biosciences) (Li et al., 1989). The radiograph of the axonal lysates in conjunction with the gold-stained protein content from the same nitrocellulose membrane was aligned with Coomassie-stained preparative 2D gels from whole DRG lysates by overlaying the transparent sheet of the autoradiogram on the aurodye blot and the preparative gel containing the whole DRG lysates. The matching spots were excised from the preparative gel, digested with tryp$\sin$, and analyzed using matrix-assisted laser desorption/ionization timeof-flight/time-of-flight mass spectrometry (MALDI-TOF/TOF MS) as described previously ( $\mathrm{Li}$ et al., 2004). To reconcile any variabilities between individual 2D gels that could lead to misidentification of closely migrating spots, independent RT-PCR studies were used to verify that the DRG axons contained the mRNAs for each protein identified by the MALDI-TOF/TOF MS (see below).

Immunoprecipitation. For immunoprecipitation, sheared axons were incubated in $10 \mu \mathrm{g} / \mathrm{ml}$ cycloheximide or $25 \mu \mathrm{g} / \mathrm{ml}$ chloramphenicol for $30 \mathrm{~min}$ before metabolic labeling in $2 \mathrm{mCi} / \mathrm{ml}\left[{ }^{35} \mathrm{~S}\right]$ methionine/cysteine for $4 \mathrm{~h}$. The metabolically labeled preparations were rinsed in warm PBS and then lysed for $30 \mathrm{~min}$ in RIPA buffer (150 mm NaCl, $50 \mathrm{~mm}$ Tris, $1 \%$ Triton X-100, $0.1 \%$ SDS, $0.5 \%$ sodium deoxycholate). Insoluble debris was cleared by centrifugation at $15,000 \times g$ for $15 \mathrm{~min}$. Lysates were precleared by $30 \mathrm{~min}$ incubation with $20 \mu \mathrm{l}$ of protein A/G-Plus agarose (Santa Cruz Biotechnology, Santa Cruz, CA) at $4^{\circ} \mathrm{C}$, followed by centrifugation at $1000 \times g$ for $5 \mathrm{~min}$. Protein content in the cleared lysates was quantitated using the NanoOrange reagent following the instructions of the manufacturer (Molecular Probes, Eugene, OR). The lysates were normalized for protein content and processed for immunoprecipitation with anti-calreticulin $(6 \mu \mathrm{g} / \mathrm{ml}$; Stressgen, Victoria, British Columbia, Canada), anti-peripherin $(10 \mu \mathrm{g} / \mathrm{ml}$; Chemicon, Temecula, CA), antiHsp70 (9 $\mu \mathrm{g} / \mathrm{ml}$; Sigma), anti-Park7 (human ortholog of rat SP22; 10 $\mu \mathrm{g} / \mathrm{ml}$; Abcam, Cambridge, MA), or anti-superoxide dismutase 1 (SOD1) $(12.6 \mu \mathrm{g} / \mathrm{ml}$; Calbiochem, La Jolla, CA). After overnight incubation in primary antibody at $4^{\circ} \mathrm{C}, 20 \mu \mathrm{l}$ of protein A/G-Plus agarose antibody was added for $1 \mathrm{~h}$ at $4^{\circ} \mathrm{C}$ with rotation. Immunocomplexes were collected by centrifugation at $1000 \times g$ for 5 min and the agarose pellets were gently washed four times with RIPA buffer. After the final wash, the immunocomplexes were denatured in Laemmli sample buffer, boiled for 5 min, and fractionated by SDS-PAGE gels. Gels were incubated in Enhance reagent (Amersham Biosciences), dried, and exposed to preflashed Hyperfilm-MP (Amersham Biosciences) at $-80^{\circ} \mathrm{C}$.

RNA isolation. RNA was extracted from fractionated cultures using the RNAqueous Micro kit (Ambion, Austin, TX). RNA was extracted from rat brain using guanidium isothiocyanate by standard methods (Chro- 
Table 1. Summary of primers used for PCR analyses

\begin{tabular}{|c|c|c|c|c|}
\hline mRNA & Spot number & Accession number & Sense primer $\left(5^{\prime}\right.$ to $\left.3^{\prime}\right)$ & Antisense primer $\left(5^{\prime}\right.$ to $\left.3^{\prime}\right)$ \\
\hline Calreticulin & 1 & NM_022399 & ACGAGCCAAGATTGATGACC & TGGCCTCTACAGCTCATCCT \\
\hline grp78/BiP & 2,3 & M14050 & AGTGGTGGCCACTAATGGAG & TCAAATTTGGCCCGAGTAAG \\
\hline$\beta$-Actin & $4,5,9,10$ & NM_031144 & GCGGACTGTTACTGAGCTGCG & TTTATTCGGTCTCACGTCAGT \\
\hline grp75 & 6,8 & S78556 & CAGAGCCCCAAGTAAAGCTG & TCTGTTGCTCACGTCCTGTC \\
\hline HSP70 & 7 & L16764 & GAGTTCAAGCGCAAACACAA & CTCAGACTTGTCGCCAATGA \\
\hline Vimentin & 11,12 & NM_031140 & TTTAAGCTTGCCGCAGCCTCTATTCCTCA & TTTCTCGAGTCCCGCATCTCCTCCTCGTA \\
\hline Peripherin & 16,17 & NM_012633 & GCTGGATCTCTGAGGCTGAC & ATGGGGTCATTCTTGAGCAG \\
\hline HSP60 & 18 & $X 53585$ & ACCTGTGACAACCCCTGAAG & TCTTCCTGTTGTCCCCAAAC \\
\hline$\gamma \mathrm{Tpm} 3$ & 19 & NM_057208 & GCAAAGCACATTGCAGAAGA & TCTCCGCCTCCTTGAGTTTA \\
\hline$\gamma$-Synuclein & 20 & NM_031688 & CAGCCAGGTCTCTTCCTCAC & TGAGCCTCTGTGGTTGACTG \\
\hline Uch-L1 & 21 & NM_017237 & GATTAACCCCGAGATGCTGA & AGGGGACAACTTCTCCGTTT \\
\hline 1-Cys Peroxiredoxin (peroxiredoxin 6) & 22 & NM_053576 & TCATGGGGCATTCTCTTTTC & GGGGCGTATAACGGAGGTAT \\
\hline HSP27 & 23 & NM_031970 & TGTCAGAGATCCGACAGACG & TACTGGGGATGGGTAGCAAG \\
\hline hnRNP H' & 24,25 & $a$ & AATGGATTGGGTGTTGAAGC & СCTGTGCCCTATTCTTTCCTT \\
\hline Dismutase (superoxide dismutase 1) & 26 & X05634 & GGATTAACTGAAGGCGAGCA & CAATCACACCACAAGCCAAG \\
\hline ATP synthase subunit d & 27 & NM_019383 & GGAAACGATCTGAAGTCCTG & TGCTTCACAGGTTCTCGATG \\
\hline$\alpha$ Enolase 1 & 28 & NM_012554 & GCCTCCTGCTCAAAGTGAAC & TTCAGAGGGCTCCAGACACT \\
\hline Dimethylarginine dimethylaminohydrolase 2 & 29 & NM212532 & GAGGCAACGACTAGGTCTGC & CCGTAGAGACAGCGAAGTCC \\
\hline SP22 & 30 & NM_057143 & CATCCTAGCCAAAGGAGCAG & CCAAAGCCTACTTCGTGAGC \\
\hline ERp29 & 31 & NM_053961 & CCTGAAGATCATGGGGAAGA & ATGGTCTCAGCAGCCTCAGT \\
\hline Peptidyl isomerase A (cyclophillin A) & 32 & NM_017101 & AGCACTGGGGAGAAAGGATT & AGATGCCAGGACCTGTATGC \\
\hline Cofilin 1 & 33 & NM_017147 & TGTGGCTGTCTCTGATGGAG & TTGTCTGGCAGCATCTTGAC \\
\hline$\alpha \mathrm{B}$ crystallin & 34 & $X 60352$ & TTCTTCGGAGAGCACCTGTT & TCCGGTACTTCCTGTGGAAC \\
\hline Peroxiredoxin 1 & 35 & NM_057114 & CTTCTGTCATCTGGCATGGA & AAAGAGGCCCCTGAAAGAGA \\
\hline Glyceraldehyde 3-phosphate dehydrogenase & 37 & NM_017008 & GGAGAAACCTGCCAAGTATG & AGACAACCTGGTCCTCAGTG \\
\hline PGK 1 & 38,39 & NM_053291 & GCAAAGACTGGCCAAGCTAC & CTTCCAGGAGCTCCAAACTG \\
\hline Aldolase C & 40 & X06984 & TGAGCCAAATTGGGGTAGAG & AGAATGCCCTTCTCCTGGAT \\
\hline HSP90 & & S45392 & AAGGCTGAGGCAGACAAAAA & CACCCAACCCTGCTATCTGT \\
\hline$\gamma$-Actin & & X52815 & GCAGATGGACTGAGCAGGTGCCAGG & CTTTTATTTCTCTTTACACAAT \\
\hline 12S mitochondrial rRNA & & NC_00165 & CCCAGAGAACATTAGG & GAGGAGGGTGACGGGCGG \\
\hline
\end{tabular}

With the exception of calreticulin and $\beta$-actin, primer pairs were used for standard PCR and for quantitative PCR analyses by SybrGreen assays. See Materials and Methods for primers for quantitative analyses of calreticulin and $\beta$-actin transcripts. Nomenclature for mRNAs follows the protein designation from MS analyses (Table 2). Spot number refers to that designated from 2D gels in MS analyses (Table 2). Accession number is the GenBank accession number. Alternate protein names are provided in parentheses.

${ }^{a}$ Rat hnRNPH' primers were constructed from regions of sequence homology between human (NM_019597) and mouse (NM_019868) hnRNP h' cDNAs.

mozinski and Sacchi, 1987). RNA was quantified by fluorometry using RiboGreen reagent (Molecular Probes).

Analyses of axonal RNAs. For detection of axonal transcripts, $200 \mathrm{ng}$ of RNA from cell body and axons was used as template for RT with SuperScript II (Invitrogen, Carlsbad, CA) and an oligo(dT) primer at $42^{\circ} \mathrm{C}$ for $1 \mathrm{~h}$. The RT reactions were diluted 10-fold and used for transcriptspecific PCR with AmpliTaq DNA polymerase (Applied Biosystems, Foster City, CA). Primer sequences used for PCR are outlined in Table 1. These "standard" PCRs were incubated for $1 \mathrm{~min}$ at $95^{\circ} \mathrm{C}$ and then cycled 35 times for $45 \mathrm{~s}$ at $95^{\circ} \mathrm{C}, 45 \mathrm{~s}$ at $58^{\circ} \mathrm{C}$, and $1 \mathrm{~min}$ at $72^{\circ} \mathrm{C}$. Negative control for amplification consisted of RNA processed without the addition of reverse transcriptase. Standard PCRs were resolved on ethidium bromide-stained agarose gels.

For more sensitive detection of RNAs, axonal RNA template was normalized for protein content (see below), and RT-PCR was performed as above, except $0.5 \mu \mathrm{Ci}\left[\alpha-{ }^{32} \mathrm{P}\right] \mathrm{dCTP}$ was included in the PCR. For these "hot" PCRs, $15 \mu \mathrm{l}$ aliquots were removed every fifth cycle as indicated and resolved on acrylamide gels followed by phosphorimaging. For quantitative RT-PCR, the standard RT reactions above were amplified using the ABI Prism 7900HT sequence detection system (Applied Biosystems). These reactions were performed using the SybrGreen 2X Master Mix for all transcripts except $\beta$-actin, which was detected using the TaqMan Universal PCR Master Mix and the rodent $\beta$-actin Assay on Demand primers and probe (Rn00667869_m1; Applied Biosystems). Primers used for the SybrGreen assays were the same as those used for detection of axonal transcripts (Table 1), except for calreticulin (forward, 5'-ACGAGCCAAGATTGATGACC-3'; reverse, 5' -TTCCATTCGCCCTTGTATTC- $3^{\prime}$ ). All standards and samples were assayed in quadruplicate for three independent experiments. Thermal cycling was initiated with an initial denaturation at $50^{\circ} \mathrm{C}$ for $2 \mathrm{~min}$ and $95^{\circ} \mathrm{C}$ for $10 \mathrm{~min}$ followed by 40 cycles at $95^{\circ} \mathrm{C}$ for $15 \mathrm{~s}$ and $60^{\circ} \mathrm{C}$ for $1 \mathrm{~min}$. Relative levels of individual transcripts were quantitated by normalizing to the $12 \mathrm{~S}$ mitochondrial rRNA control using a comparative threshold value $\left(C_{t}\right)$ method. Briefly, the $C_{\mathrm{t}}$ for each transcript was determined using the automatic $C_{\mathrm{t}}$ algorithm of the ABI Prism SDS 2.1 software to calculate the optimal baseline range and threshold values. Individual $\Delta C_{\mathrm{t}}$ values were then determined by subtracting the $12 \mathrm{~S}$ mitochondrial rRNA $C_{\mathrm{t}}$ value from the individual transcript $C_{\mathrm{t}}$ values. From this, the calculation of $\Delta \Delta C_{\mathrm{t}}$ was determined by subtracting the $\Delta C \mathrm{t}$ calibrator value (i.e., BSA control). The fold difference was then expressed as $2^{-\Delta \Delta \mathrm{Ct}}$, with $\Delta \Delta C_{\mathrm{t}}+$ $s$ and $\Delta \Delta C_{\mathrm{t}}-s$, where $s$ is the SD of the $\Delta \Delta C_{\mathrm{t}}$ values. Transcript levels are expressed relative to the $\Delta \Delta C_{\mathrm{t}}$ values of the BSA-treated axons.

Immunofluorescence. Immunofluorescence was performed on $20-22 \mathrm{~h}$ dissociated DRG cultures or sections of sciatic nerve (immediately proximal to crush site) that had been prepared from injury-conditioned animals. For cultures, coverslips were rinsed in PBS and then fixed in $4 \%$ paraformaldehyde for $20 \mathrm{~min}$ at room temperature. Tissues were fixed overnight in $4 \%$ paraformaldehyde, cryoprotected in buffered $30 \%$ sucrose, and processed for cryostat sectioning. Immunofluorescence was performed as described previously (Zheng et al., 2001) using the following primary antibodies: $\alpha \mathrm{B}$ crystallin (1:200; Calbiochem), calreticulin (1:200; Stressgen), grp75 (1:200; Oxford Biochemical, Oxford, MI), grp78/BiP (1:250; Stressgen), HSP60 (1:100; Stressgen), HSP27 (1:100; Stressgen), HSP70 (1:200; Sigma), HSP90 (1:100; Stressgen), neurofilament (mouse, 1:1000; Zymed, South San Francisco, CA) (chick, 1:500; Chemicon), peripherin (1:1000; Chemicon), sarcoplasmic/endoplasmic reticulum $\mathrm{Ca}^{2+}$ ATPase (SERCA) 2/3 (1:50; Santa Cruz Biotechnology), SOD1 (1:300; Calbiochem), SP22 (DJ-1/Park7) (1:400; Abcam), and $\gamma$-synuclein (1:200; Abcam). Secondary antibodies consisted of FITC, Texas Red, or cyanine 5 (Cy5) (1:400; Jackson ImmunoResearch, West Grove, PA), Alexa488, or Alexa555 (1:800; Molecular Probes) conjugated anti-rabbit, anti-goat, anti-sheep, or anti-mouse. Fluorescence was ana- 

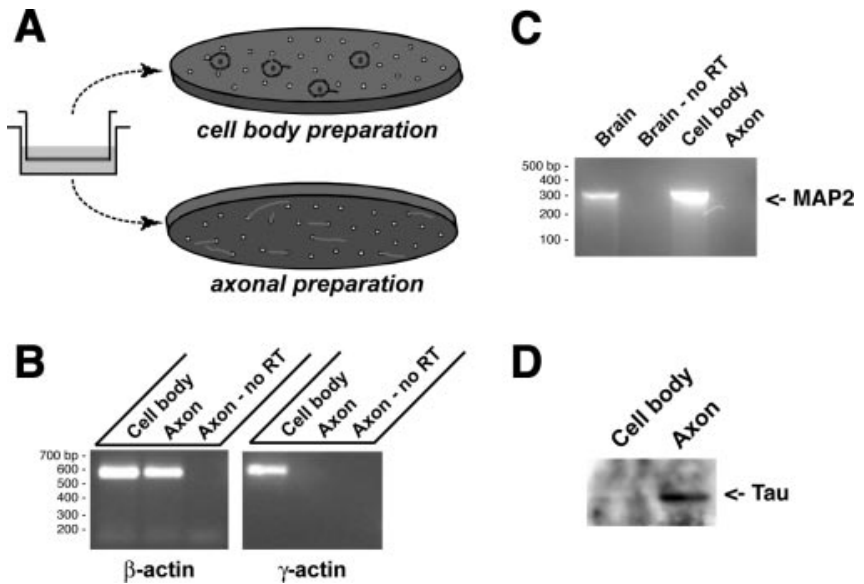

Figure 1. Isolation of DRG axons. A, Schematic of the DRG culture method for isolation of axons is illustrated. Dissociated DRGs are cultured in tissue culture insert with polyethylene tetraphthalate membrane with 8- $\mu \mathrm{m}$-diameter pores shown to the left. The neuron cell bodies (green) and non-neuronal cells (red) remain on the upper membrane surface. Axons traverse to the underside of the membrane through the pores. $B, \beta$-Actin was amplified using RNA from either the cell body or the axons as a template, but $\gamma$-actin mRNA could only be amplified from the cell-body RNA. Axonal RNA processed for RT-PCR without the addition of reverse transcriptase shows that the $\beta$-actin PCR product detected in the axons is specific for amplification of mRNA. C, RT-PCR was used to determine whether axons contained MAP2 mRNA. In this case, rat brain RNA was used for both positive and "no RT" control for PCR. Note that the DRG cell body contains even more MAP2 mRNA than does the total rat brain RNA, but no MAP2 was amplified from the axonal preparation. D, Protein extracted from the cell body and axonal preparations (10 $\mu \mathrm{g} /$ /ane) was separated by $10 \%$ SDS-PAGE and transferred to PVDF membrane. By immunoblotting, a band corresponding to tau was clearly visible in the axonal preparation, but only a faint band can be seen in the cell-body fraction.

lyzed using an upright Leica (Nussloch, Germany) microscope with Hamamatsu (Shizouka, Japan) ORCA camera or inverted Leica TCS/SP2 confocal microscope using sequential scanning. XZ sectioning was performed with a galvanometer stage.

Localized neurotrophin treatment of axons. DRGs were cultured on tissue culture inserts as above including addition of the RNA synthesis inhibitor 5,6-dichlorobenzimidazole riboside (DRB) throughout the culture period ( $80 \mu \mathrm{M}$; Sigma). NGF (100 ng/ml; Harlan, Indianapolis, IN), BDNF (Promega, Madison, WI), or BSA (Sigma) was absorbed to 20 - $\mu \mathrm{m}$-diameter polystyrene microparticles following the instructions of the manufacturer (Polysciences, Warrington, PA). Efficiency of ab- sorption was determined by Bradford assay. NGF-, BDNF-, or BSAabsorbed microparticles added to cultures corresponded to an equivalent of $200 \mathrm{ng} / \mathrm{ml}$ soluble protein.

To determine the effectiveness of the neurotrophin-adsorbed beads and whether any detectable levels of ligand are released from the absorbed beads over the period of exposure to axons (see below), NGF- and BSA-adsorbed beads from above were incubated in culture medium for $4 \mathrm{~h}$ at $37^{\circ} \mathrm{C}$. After incubation, the beads were pelleted, and either the protein-absorbed beads or the supernatant was added to serum-starved PC12 cells for $5 \mathrm{~min}$. The PC12 cells were rinsed in ice-cold PBS and then lysed in $50 \mathrm{~mm}$ Tris-Cl, pH 7.4, $300 \mathrm{~mm} \mathrm{NaCl}, 1 \%$ Triton X-100, 10\% glycerol, 10 mм EGTA, $10 \mathrm{~mm} \mathrm{NaF}, 2$ mм paranitrophenol phosphate, 1 $\mu \mathrm{g} / \mathrm{ml}$ leupeptin, $10 \mathrm{~mm}$ sodium ortho-vanadate, and $100 \mu \mathrm{M}$ PMSF for $20 \mathrm{~min}$ at $4^{\circ} \mathrm{C}$. Lysates were cleared by centrifugation at $15,000 \times g$ for 15 min and protein content assessed by Bradford assay (Bio-Rad, Hercules, CA). Lysates were normalized for protein content and then levels of phosphorylated TrkA assessed by immunoblotting (see above) (Chang et al., 2003).

For treatment of axons with the NGF- and BDNF-absorbed beads, the axonal compartment was selectively exposed to the absorbed beads by placing the inserts into dishes with shallower wells such that the membrane undersurface directly contacted the settled microparticles. After $4 \mathrm{~h}$, the filters were rinsed in PBS, and axonal RNA was extracted as above. For analyses of potential transcriptional-induced changes in RNA levels, axons were scraped away from cultures after a $4 \mathrm{~h}$ treatment of the axonal compartment with microparticles; RNA was then isolated from the cell-body compartment and used for RT-PCR. To analyze for changes in RNA survival with axonal neurotrophin treatment, axons were first sheared from the cell body as described above and then isolated axons were exposed to microparticles for $4 \mathrm{~h}$ followed by isolation of axonal RNA. Protein in the axonal and cell-body samples was quantitated using NanoOrange reagent. Axonal RNA samples were normalized to protein content and then used for RT-PCR. Initial analyses of these RNA samples were performed by "hot PCR" and then by real-time PCR (see above).

\section{Results}

\section{Local synthesis of proteins by sensory axons}

In previous work, we devised a means to separate DRG processes from cell-body and non-neuronal cells by culturing neurons on a porous membrane that allows passage of axons but restricts the cell-body and non-neuronal cells to the upper membrane surface (Fig. 1A) (Zheng et al., 2001). By virtual Northern blotting, $\gamma$-actin mRNA, which exclusively resides in the neuronal cell
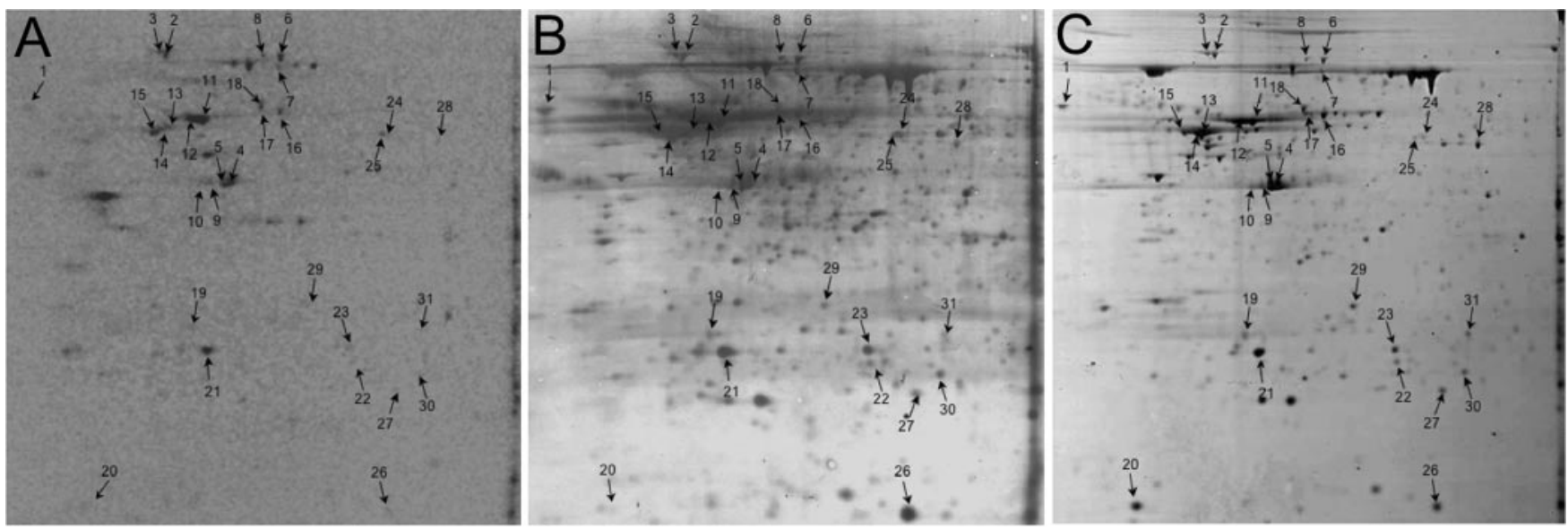

Figure 2. Two-dimensional separation of radiolabeled isolated axons. Representative images from $2 \mathrm{D} \mathrm{gels}$ (first dimension, $\mathrm{pH} 4-7$; second dimension, $11 \% \mathrm{SDS}$-PAGE) from ${ }^{35} \mathrm{~S}$-labeled axonal preparations $(A, B)$ and preparative gel from whole DRG culture lysates $(C)$ are shown. Approximately the $4 \times 10^{6} \mathrm{cpm}$ was fractionated by $2 \mathrm{D}$ gel electrophoresis in the gel shown in $A$ and $B$. $A$ shows the image of radioactive proteins by phosphorimaging; $B$ shows the aurodye stain for total proteins in the blot from $A$. C shows preparative gel of whole DRG lysates that was stained with Coomassie. The numbered spots indicate proteins that could be aligned between the gels. These spots were excised from the preparative gel and processed for MS analyses (Table 2). Images of pH 3-10 gels are included in supplemental data (Fig. S1, available at www.jneurosci.org as supplemental material). 
Table 2. Mass spectrometric characterization of axonally synthesized proteins

\begin{tabular}{|c|c|c|c|c|c|c|}
\hline Spot & Protein identification & MS & MS/MS & MW & $\mathrm{pl}$ & Accession number \\
\hline 1 & Calreticulin & 80 & & 48217 & 4.33 & 11693172 \\
\hline 2 & $\operatorname{grp} 8 / \mathrm{BiP}^{a}$ & 187 & 122 & 72667 & 5.12 & 109893 \\
\hline 3 & grp78/Bip ${ }^{a}$ & 226 & 152 & 72667 & 5.12 & 109893 \\
\hline 4 & $\beta$-Actin & 125 & 517 & 42338 & 5.29 & 71620 \\
\hline 5 & $\beta$-Actin & 145 & 476 & 42338 & 5.29 & 71620 \\
\hline 6 & grp75 precursor & 176 & 129 & 74272 & 5.87 & 2119726 \\
\hline 7 & HSP70 & 65 & & 69961 & 5.44 & 92355 \\
\hline 8 & grp75 precursor & 73 & & 74272 & 5.87 & 2119726 \\
\hline 9 & $\beta$-Actin & 85 & 191 & 42338 & 5.29 & 71620 \\
\hline 10 & $\beta$-Actin & 105 & 155 & 42338 & 5.29 & 71620 \\
\hline 11 & Vimentin & 280 & & 53933 & 5.06 & 14389299 \\
\hline 12 & Vimentin & 360 & 112 & 53933 & 5.06 & 14389299 \\
\hline 13 & $\beta$-Tubulin chain 15 & 154 & 226 & 50665 & 4.79 & 92930 \\
\hline 14 & $\beta$-Tubulin chain 15 & 148 & 221 & 50665 & 4.79 & 92930 \\
\hline 15 & $\beta$-Tubulin chain 15 & 87 & & 50665 & 4.79 & 92930 \\
\hline 16 & Peripherin & 349 & 123 & 53743 & 5.37 & 6981416 \\
\hline 17 & Peripherin & 171 & 76 & 53743 & 5.37 & 6981416 \\
\hline 18 & HSP60 & 209 & 90 & 58301 & 5.35 & 1334284 \\
\hline 19 & Tropomyosin & 43 & & 28854 & 4.79 & 7441398 \\
\hline 20 & $\gamma$-Synuclein ${ }^{a}$ & 58 & 22 & 13184 & 4.68 & 6755592 \\
\hline 26 & Dismutase (superoxide dismutase 1) & 53 & 80 & 15756 & 5.89 & 818029 \\
\hline 27 & ATP synthase subunit d & 35 & & 18891 & 5.78 & 220904 \\
\hline 21 & Uch-L1 & 96 & & 25204 & 5.12 & 8394506 \\
\hline 22 & 1-Cys Peroxiredoxin (peroxiredoxin 6) & 57 & & 24924 & 5.64 & 16758348 \\
\hline 23 & HSP27 & 138 & 134 & 22952 & 6.12 & 1170367 \\
\hline 28 & $\alpha$ Enolase 1 & 145 & 38 & 47572 & 6.16 & 6978809 \\
\hline 24 & $\mathrm{hnRNPH} 1^{a}$ & 35 & & 49693 & 5.89 & 10946928 \\
\hline 25 & $\mathrm{hnRNPH^{ \prime a }}$ & 30 & & 49821 & 5.89 & 9845253 \\
\hline 29 & Dimethylarginine dimethylaminohydrolase 2 & 94 & 27 & 25587 & 5.69 & 7949035 \\
\hline 30 & SP22 & 80 & & 20285 & 6.32 & 16924002 \\
\hline 31 & Erp29 & 78 & 35 & 28694 & 6.23 & 16758848 \\
\hline 32 & Peptidyl isomerase A (cyclophilin A) & 100 & 53 & 18171 & 8.34 & 8394009 \\
\hline 33 & Cofilin 1, nonmuscle & 50 & 19 & 18813 & 8.22 & 83933101 \\
\hline 34 & $\alpha \mathrm{B}$ crystallin & 109 & 42 & 19977 & 6.84 & 57580 \\
\hline 35 & Peroxiredoxin 1 & 110 & 27 & 22371 & 8.27 & 16923958 \\
\hline 36 & Glyceraldehyde 3-phosphate dehydrogenase & 74 & 11 & 36250 & 8.14 & 8393418 \\
\hline 37 & Glyceraldehyde 3-phosphate dehydrogenase & 71 & 11 & 36250 & 8.14 & 8393418 \\
\hline 38 & Phosphoglycerate kinase 1 & 88 & 6 & 45149 & 7.53 & 16757986 \\
\hline 39 & Phosphoglycerate kinase 1 & 59 & & 45149 & 7.53 & 16757986 \\
\hline 40 & Aldolase C & 123 & & 39654 & 6.78 & 1334163 \\
\hline
\end{tabular}

The spot number corresponds to the protein spot numbers indicated in Figure 2. Mass spectra were searched against the National Center for Biotechnology Information database using Mascot software from Matrix Science. For all samples, the tryptic peptide mass fingerprints generated by single-staged mass spectrometry were searched, and the Mascot score is listed under MS. For some of the proteins, tandem mass spectrometry was performed on several peptides, and the Mascot scores of the daughter ion spectra are listed under MS/MS. Protein identities were preferentially selected from the Mascot report based on the species Rattus norvegicus.

${ }^{a}$ In several cases in which Mascot scores for R. norvegicus were very low or not listed in the report, the protein identities from Mus musculus were selected. Many distinct proteins were detected as trains of multiple spots, strongly suggesting that the posttranslational modified forms, such as phosphorylation, that alter the pl of the proteins were present.

body of developing neurons (Bassell et al., 1998), appeared to be excluded from the axonal compartment of these cultures. We have now used a more sensitive detection method, RT-PCR with transcript specific primers, to unequivocally demonstrate the purity of the DRG axonal preparation. For this, RNA was extracted from axonal or cell-body preparations of $20 \mathrm{~h}$ cultures of injuryconditioned L4-5 DRGs (Fig. 1A). By RT-PCR, $\gamma$-actin mRNA could not be amplified from axonal RNA, but there was abundant $\gamma$-actin mRNA in the cell-body RNA isolates (Fig. $1 B$ ). This indicates that the DRG processes isolated from the membranes were not contaminated with small quantities of RNA from the DRG cell bodies or Schwann cells, confirming our previous results (Zheng et al., 2001). To assess the exclusive axonal nature of the preparation, we determined whether MAP2 mRNA, which resides in the cell soma and dendrites but is restricted from axons (Garner et al., 1988), could be amplified from the axonal RNA. MAP2 mRNA was easily amplified from the DRG cell body but was not detectable in the axonal RNA samples, even with ex- tended cycles (Fig. 1C). This indicates that the DRG axons do not contain any MAP2 mRNA consistent with our previous findings that MAP2 protein does not extend into the axon (Zheng et al., 2001). As a further gauge of axonal purity, we used protein lysates from the DRG axons and cell bodies for immunoblotting with antibodies to Tau. Levels of Tau were substantially higher in the axonal preparation such that the cell-body signal was barely visible when the axonal signal was saturated (Fig. 1D).

By standard one-dimensional SDS-PAGE, sheared DRG axons incorporate $\left[{ }^{35} \mathrm{~S}\right]$ methionine into several different proteins (Zheng et al., 2001). To gain a better estimate of how many proteins are synthesized in the axonal compartment, we resolved labeled axonal preparations by 2D gel electrophoresis. For this, sheared axons from $16 \mathrm{~h}$ cultures were metabolically labeled with $\left[{ }^{35} \mathrm{~S}\right]$ methionine/cysteine. Axons sheared from the cell body show initial retraction of the cut proximal axon and distal axon halts extending but does not retract unless protein synthesis is inhibited (Zheng et al., 2001). The axons remain microscopically 

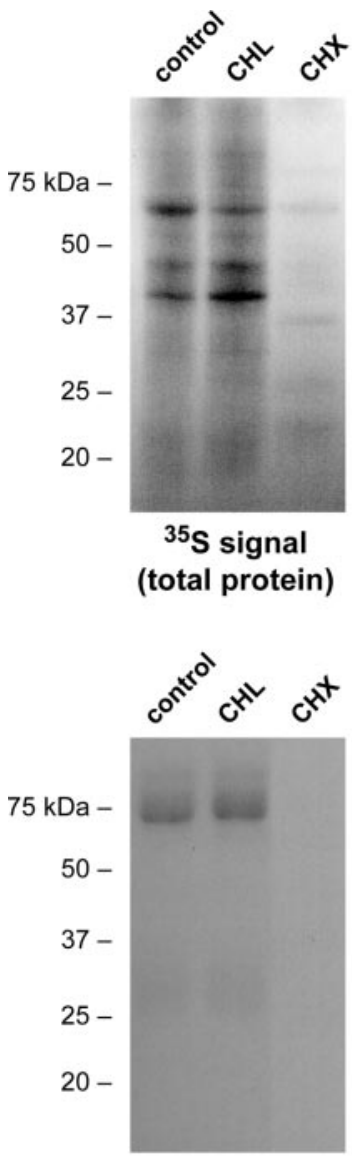

HSP70
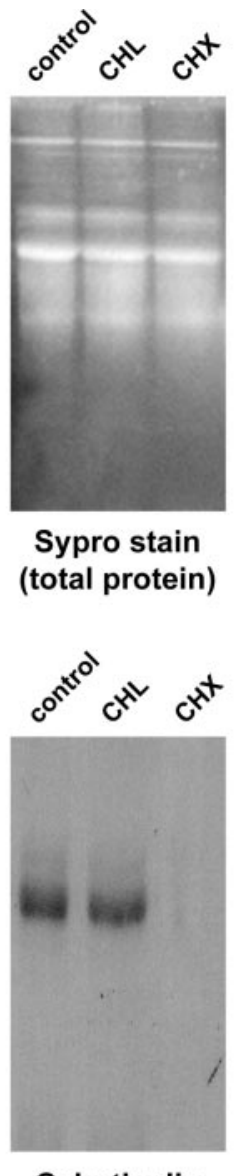

Calreticulin

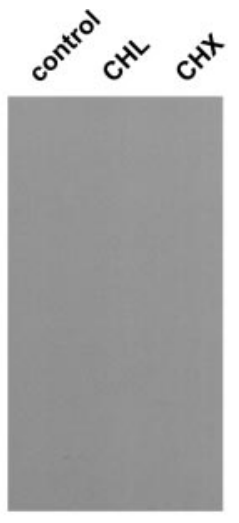

No Primary

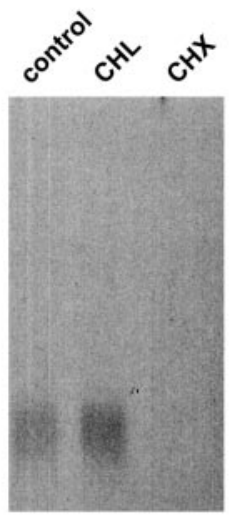

SP22

Figure 3. Axoplasmic protein synthesis. Sheared axons were pretreated with $25 \mu \mathrm{g} / \mathrm{ml}$ chloramphenicol (CHL), $10 \mu \mathrm{g} / \mathrm{ml}$ cycloheximide (CHX), or vehicle (Control) for $20 \mathrm{~min}$, and then $2 \mathrm{mCi} / \mathrm{ml}^{35}\left[{ }^{35}\right.$ ] methionine/cysteine was added for $4 \mathrm{~h}$. The first two panels show fractionated lysates from the axons with total protein visualized by Sypro Ruby stain (Sypro) and labeled proteins visualized by autoradiography ( $3 \mathrm{~d}$ exposure). The remainder of the panels show autoradiograms of immunoprecipitated proteins indicated (peripherin, $\approx 54 \mathrm{kDa}$; HSP70, $\approx 70 \mathrm{kDa}$; calreticulin, $\approx 48 \mathrm{kDa}$; Uch-L1, $\approx 25 \mathrm{kDa} ; S P 22, \approx 20 \mathrm{kDa} ; S 0 \mathrm{D1}, \approx 15 \mathrm{kDa}$ ). Note that newly synthesized proteins are detected in the control and CHL lanes but not in the CHX lane, whereas the Sypro stain of the lysates before immunoprecipitation shows approximately equivalent levels of unlabeled proteins in all lanes.

intact over $4 \mathrm{~h}$ incubation and, as established by TCA precipitation, incorporation of $\left[{ }^{35} \mathrm{~S}\right]$ methionine/cysteine into proteins continues for at least $6 \mathrm{~h}$ after removal of the cell body (data not shown). For all the experiments outlined below, we restricted the metabolic labeling duration to $4 \mathrm{~h}$ to maximize isotope incorporation while minimizing any chances of degradation of the sheared axons. For 2D electrophoresis, axonal lysates were mixed with unlabeled DRG lysates and separated on $\mathrm{pH} 4-7$ and 3-10 IPG strips, followed by $11 \%$ SDS-PAGE (Fig. $2 A, B$ ) (supplemental Fig. S1, $A$ and $B$, available at www.jneurosci.org as supplemental material). For comparison, unlabeled lysates from whole DRG cultures were identically electrophoresed and stained for total protein (Fig. 2C) (supplemental Fig. S1C, available at www.jneurosci.org as supplemental material). Radioisotope imaging showed many distinctly migrating ${ }^{35} \mathrm{~S}$-labeled spots in the axonal gel blots. Counting individual "spots" in the radioisotope images suggests that the DRG axons can synthesize at least 100 protein species. Comparing the axonal radioisotope image to the Coomassiestained gel of whole DRG lysates allows matching of spots in these preparations. A number of radioactive spots in the axonal images could not be aligned with the whole DRG lysate gels, arguing that these locally synthesized proteins are of low abundance relative to total cellular protein.

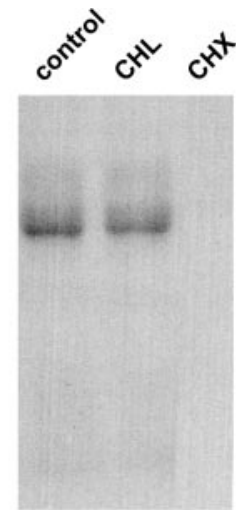

Peripherin
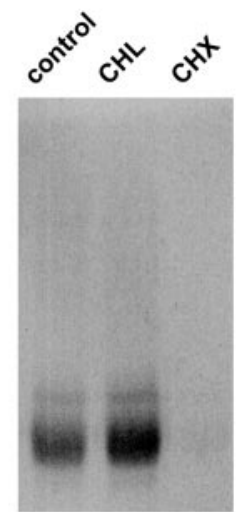

SOD1

\section{Identification of axonally}

synthesized proteins

To identify the axonally synthesized proteins, aligned spots were excised from the preparative gels and trypsin digested. Digested proteins were subjected to MALDI TOF/TOF MS, and some peptides were further subjected to MS/MS sequencing. Both MS and MS/MS spectra were searched against the Mascot database online search engine (Matrix Science) for protein identity. The summary of database search results is shown in Table 2. Mascot score $\geq 72$ for $\mathrm{MS}$ and $\geq 48$ for $\mathrm{MS} / \mathrm{MS}$ spectra indicates statistical significance of protein identity or extensive protein homology $(p<0.05)$. As an additional criterion for the identification of the proteins, the isoelectric point ( $\mathrm{pI}$ ) and molecular weight as deduced from the position on the $2 \mathrm{D}$ gel had to agree with the Mascot identification before being considered as potentially valid.

Considering that the proteins outlined in Table 2 were identified from preparative gels of total DRG lysates and the ambiguity that can occur in aligning individual 2D gels, the possibility of protein misidentification from comigrating or closely migrating spots in these individual gels remained a possibility. This is particularly so for proteins from regions of the preparative gels with high spot density. Furthermore, a number of proteins did not reach statistical significance in the Mascot score. Thus, we performed independent studies to provide additional evidence for axonal synthesis of the identified proteins. To rule out nonspecific incorporation or absorption of the ${ }^{35} \mathrm{~S}$-isotope, we asked whether protein labeling in the axons was sensitive to protein synthesis inhibitors. We have shown previously that cycloheximide and anisomycin block the majority of protein synthesis in sheared axons and cause rapid retraction of the most distal portion of the axons over $20 \mathrm{~min}$ treatment (Zheng et al., 2001). These functional studies argued for the importance of axonal protein synthesis in structurally maintaining the distal axon or growth cone but did not address the synthesis of specific proteins nor did they consider the contribution of mitochondrial protein synthesis. Consistent with our previous results (Zheng et al., 2001), cycloheximide effectively blocked synthesis of most proteins in the sheared axons, but chloramphenicol, an inhibitor of mitochondrial protein synthesis, had no appreciable effect on total axonal protein synthesis (Fig. 3). This indicates that the majority of axonally synthesized proteins are generated from axoplasmic rather than mitochondrial ribosomes. To address synthesis of specific proteins in the axons, proteins spanning the molecular weight range of the polypeptides and representative of each functional group identified by MS in Table 2 (i.e., cytoskeletal, heat shock, resident-ER, and neurodegenerative disease-associated proteins) were immunoprecipitated from the axons labeled as above. Newly synthesized peripherin, HSP70, calreticulin, SP22 (DJ-1/ Park7), and dismutase (SOD1) were detected in the control and 
chloramphenicol-treated but not in the cycloheximide-treated axonal preparations (Fig. 3). Axonal synthesis of $\beta$-actin protein has been shown in sympathetic axons (Eng et al., 1999; Lee and Hollenbeck, 2003), and we have previously published immunoprecipitations of newly synthesized $\beta$-actin protein from DRG axons (Hanz et al., 2003).

Considering that labeling of each protein tested above occurred on axoplasmic ribosomes and that each of the proteins identified in Table 2 is encoded by the nuclear rather than mitochondrial genome, we reasoned that detection of mRNAs in the axons would provide a much more sensitive means to show potential for axonal synthesis of the encoded proteins. RT-PCR to detect the axonal mRNAs for the cytoskeletal, HSP, resident-ER, and neurodegeneration-associated proteins is detailed in the sections below. Confirmation of the axonal localization of transcripts encoding each of the remaining proteins listed in Table 2 that are not detailed in the following sections is presented as supplemental data (Fig. S2, available at www.jneurosci.org as supplemental material). Together with the $2 \mathrm{D}$ gel analyses, these data argue that DRG axons synthesize a complex population of proteins from nuclear-encoded mRNAs.

\section{mRNAs encoding cytoskeletal elements} in the axonal compartment

Axonal synthesis of $\beta$-actin and tubulin has been demonstrated previously (Koenig, 1989; Eng et al., 1999; Zhang et al., 1999; Zheng et al., 2001; Lee and Hollenbeck, 2003), but peripherin, vimentin, cofilin, and tropomyosin proteins, identified by MS, have not been included previously among axonally synthesized proteins. By RT-PCR, we were able to detect peripherin, vimentin, and cofilin mRNAs in DRG axonal preparations (Fig. 4A). Localized synthesis or intra-axonal mRNA localization of ADF and $\beta$-thymosin has been demonstrated recently in rat sympathetic and Aplysia sensory axons, respectively (Lee and Hollenbeck, 2003; Moccia et al., 2003); thus, it is not surprising that cofilin protein is synthesized in the DRG axons. Axonal localization of peripherin protein is well documented (Leonard et al., 1988), and both the cultured DRG neurons and sections of sciatic nerve showed the expected intra-axonal peripherin immunoreactivity (Fig. $4 B-D$ ). Vimentin, in contrast, is not typically considered a neuronal protein (Colucci-Guyon et al., 1994), but immunolabeling showed a clear intra-axonal signal for vimentin in the injury-conditioned DRG cultures (Fig. $4 B$ ). Cryostat sections of injured sciatic nerve similarly showed vimentin immunoreactivity that colocalized with peripherin signals (Fig. 4C). Expression of vimentin by the injury-conditioned DRG neurons is consistent with previous examples of vimentin expression in developing neurons (Tapscott et al., 1981; Cochard and Paulin, 1984; Shaw et al., 1985; Yu et al., 2004).

As mentioned above, the MS data for tropomyosin did not reach statistical significance. There are several isoforms of tropomyosin, and expression of $\gamma$-tropomyosin 3 isoform ( $\gamma \mathrm{Tpm} 3$, also designated TM5) is neuronal specific (Weinberger et al., 1993; Gunning et al., 1997). By RT-PCR, $\gamma$ Tpm3 mRNA was detected in axonal preparations from the cultured DRGs (Fig. $4 A$ ). Immunolabeling with an antibody that recognizes most tropomyosin isoforms, including $\gamma \mathrm{Tpm} 3$, showed strong intraaxonal signals extending into growth cones (Fig. 4D) confirming previous axonal localization of $\gamma \mathrm{Tpm} 3$ protein (Hannan et al., 1998). Axonal synthesis of tropomyosin isoforms has been suggested previously, because axonal $\gamma$-Tpm3 mRNA was detected in developing axons, both in vitro and in vivo (Hannan et al., $1995,1998)$. Our data argue that axonal $\gamma$-Tpm 3 mRNA is indeed locally translated into new protein.

\section{Heat shock protein mRNAs in DRG axons}

Previous studies indicate that HSP27 mRNA is upregulated in sensory neurons during axonal regeneration and the protein product localizes to axons (Costigan et al., 1998). The MS data indicated that other HSP family members, including $\alpha \mathrm{B}$ crystallin, HSP27, HSP60, HSP70, grp75 and grp78/BiP, are synthesized in the DRG axons. RT-PCR using primers specific for mRNAs encoding these HSP and HSP-like proteins confirms that the axons contained each of these transcripts (Fig. 5A) (analyses of grp78/BiP is presented in the following section). Cytoplasmic HSP70 frequently functions as a heterodimer with HSP90 (Pratt and Toft, 2003). HSP90 was not among the axonally synthesized proteins outlined above, but its molecular weight is near the $2 \mathrm{D}$ gel resolution limits and, thus, may have been missed in the proteomics analyses. However, using primers specific for HSP90 mRNA, the axons also contained the transcript for this HSP70 dimerization partner providing strong evidence for its local transla- 

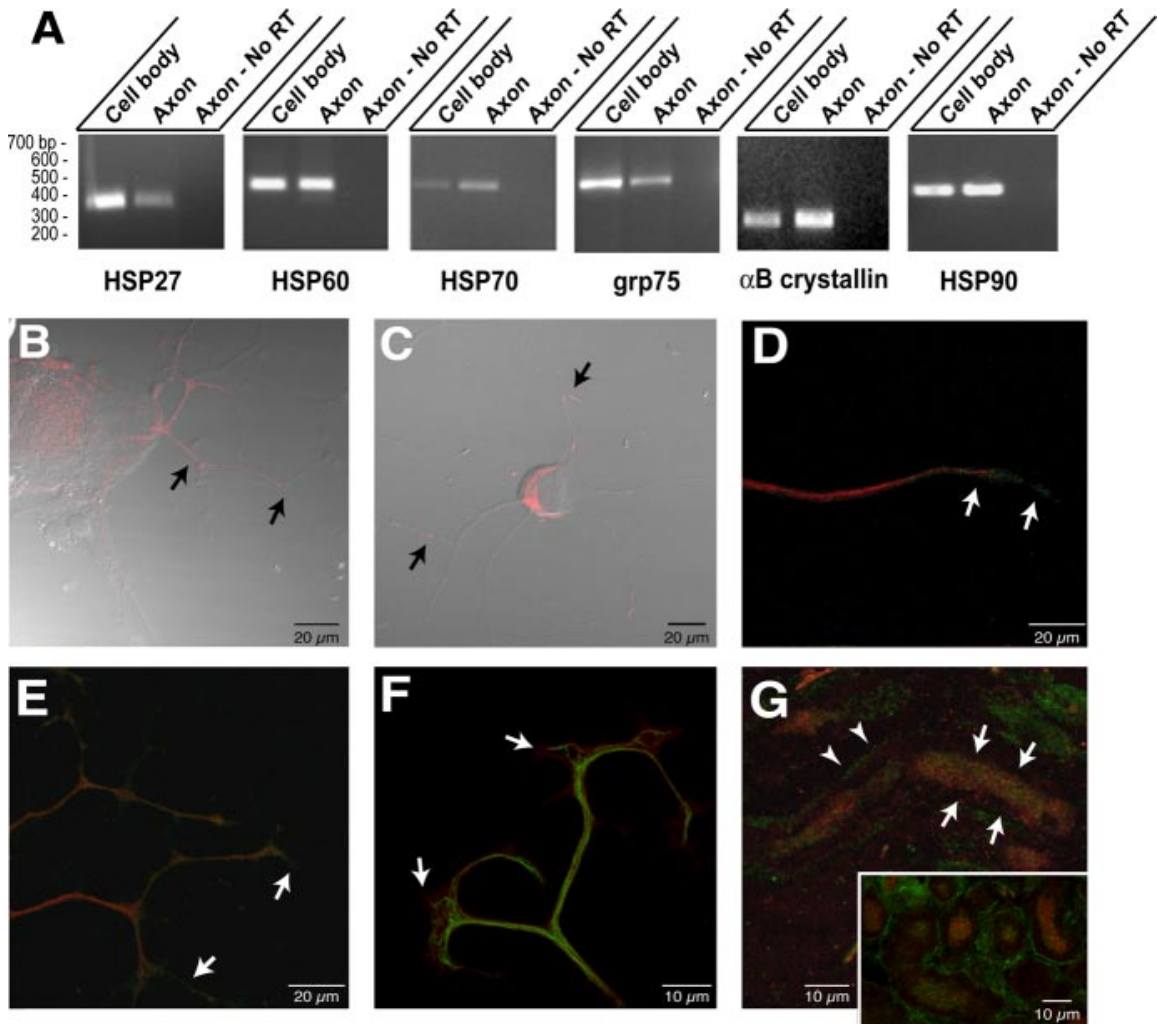

Figure 5. Heat shock and heat shock-like proteins and encoding mRNAs in regenerating axons. A, RT-PCR was performed on axonal versus cell-body RNA isolates using primers specific for $\alpha$ B crystallin, HSP27, HSP60, grp75, HSP70, and HSP90 mRNAs. Purity of the axonal preparation was determined by RT-PCR for $\beta$ - and $\gamma$-actin mRNAs as shown in Figure $1 B$. Note that each of these mRNAs was detected in the axonal RNA templates, but the relative amounts vary. HSP27 and grp75 are more abundant in the cell body than in the axon. Approximately equivalent amounts of HSP60 and HSP9O mRNAs are amplified from the cell body and axons, whereas $\alpha B$ crystallin HSP70 mRNA is relatively more abundant in the axons than in the cell-body isolates compared with the other mRNAs examined. $B$, Injury-conditioned DRG cultures were labeled for HSP60. This representative image displays a reconstructed three-dimensional projection of HSP60 (red; 15 optical XY planes taken at $0.2 \mu \mathrm{m}$ intervals) merged with a single differential interference contrast (DIC) image. Arrows show HSP60 immunoreactivity in proximal portions of the DRG axons. C, DRG cultures stained for grp75 signal (red) show intra-axonal grp75 immunoreactivity along the shaft of the axons (arrows) in this three-dimensional projection of grp75 signal (12 optical XY planes taken at $0.3 \mu \mathrm{m}$ intervals) merged with a single DIC image. D, A single optical XY plane of distal axon from DRG cultures colabeled for HSP70 (green) and peripherin (red). Arrows indicate HSP70 immunoreactivity that extends beyond the peripherin immunoreactivity into the growth cone. E, Colabeling cultures of injury-conditioned DRG neurons for HSP90 (green) and neurofilament (red) shows that HSP90 extends into the distal axon (arrows), similar to HSP70 shown in D, in this three-dimensional projection (12 optical XY planes taken at $0.2 \mu \mathrm{m}$ intervals). F, A reconstructed three-dimensional projection shows terminal axons of cultures stained for $\alpha \mathrm{B}$ crystallin (red) and neurofilament (green) (projection is from 10 optical XY planes taken at $\sim 0.15 \mu \mathrm{m}$ intervals). Note that similar to HSP70 and HSP90, $\alpha$ B crystallin immunoreactivity extends into the growth cone beyond the neurofilament signal (arrows). G, Section of sciatic nerve as in Fwas colabeled for HSP70 (green) and peripherin (red). The full panel shows a longitudinal section where intra-axonal HSP70 signal is visible in an optically isolated axon (arrows) in this projected three-dimensional image. HSP70 signal separate from the peripherin immunoreactivity is also seen in Schwann cell cytoplasm of the myelin sheath adjacent to this axon (arrowheads). The inset shows a cross section of nerve where intra-axonal HSP70 signal is clearly discerned from the bright signal in the surrounding Schwann cells.

tion (Fig. 5A). The ratios of axonal compared with cell-body mRNAs varies among these HSP transcripts. $\alpha \mathrm{B}$ crystallin and HSP70 mRNAs appeared more concentrated in the axonal than in the cellbody RNA preparations. HSP60 and HSP90 mRNAs show relatively equal levels in the axonal and cell-body RNAs, whereas HSP27 and grp75 appear more concentrated in the cell-body than in the axonal RNAs.

Costigan et al. (1998) previously demonstrated axonal localization of HSP27 protein, but axonal localization of the proteins encoded by the other HSP mRNAs amplified from the axons above has not been demonstrated. Thus, we used confocal microscopy to determine whether the protein products of these axonal HSP mRNAs also reside in axons. Immunolabeling for HSP60 showed focal immunoreactivity in the axons of cultured
DRG neurons, which was most apparent in the more proximal axon segments (Fig. $5 B)$. grp75 labeling similarly showed focal immunoreactivity along the axon shaft of cultured DRGs (Fig. 5C). In contrast, HSP70 and HSP90 immunoreactivities extended into the distal axon, often times concentrated in growth cone and adjacent regions (Fig. $5 D, E$ ). $\alpha \mathrm{B}$ crystallin immunoreactivity similarly extended into the growth cones of the cultured DRG neurons (Fig. 4F). HSP70 immunoreactivity in sections of crushed sciatic nerve showed intra-axonal signals in some, but not all, axons (Fig. 5G). Similar intra-axonal signals were seen for $\alpha \mathrm{B}$ crystallin, HSP27, HSP60, HSP90, and grp75 in sections of sciatic nerve (data not shown).

\section{Resident ER protein mRNAs in the DRG axons}

The presence of grp78/BiP, calreticulin, and ERp29 among the axonally synthesized proteins was confirmed by RT-PCR (Fig. 6A). Because grp78/BiP, calreticulin, and ERp29 are considered ER proteins, it was surprising to find their mRNAs extending into the axons when ultrastructural studies have not detected any rough ER in axons (Zelena, 1970, 1972; Peters et al., 1991; Bassell et al., 1998; Spencer et al., 2000; Zheng et al., 2001). Immunolabeling showed a clear signal for grp78/BiP, calreticulin, and ERp29 proteins in neurofilament-positive processes of cultured DRG neurons (Fig. 6B-F). The coarse granular signals for calreticulin, grp78/BiP, and ERp29 suggests a compartmentalized distribution of these axonal proteins. The immunoreactivity for these proteins in the Schwann cells of these DRG cultures is typical of resident ER proteins with their localization concentrated in a perinuclear distribution (Fig. $6 F$, inset). To further characterize the subaxonal localization of these ER proteins, we asked whether they colocalized with the SERCA, an ER marker. Much of the intra-axonal grp78/BiP and calreticulin signals overlapped with those of SERCA (Fig. 6B-E). Moreover, an additional ER marker, protein disulfide isomerase (Treiman, 2002), showed similar colocalization with calreticulin, grp78/BiP, or ERp29 (data not shown).

\section{Axonal mRNAs encoding proteins linked to neurodegenerative disorders}

Ubiquitin C-terminal hydrolase L1 (Uch-L1), SP22, $\gamma$-synuclein, and dismutase (SOD1) were detected by the MS analyses, and RT-PCR confirmed that the mRNAs encoding each of these extends into the DRG axons (Fig. 7A). Interestingly, each of these proteins, or isoforms of these proteins, has been linked to neurodegenerative diseases. Mutations in Uch-L1 and SP22, the rat ortholog of human DJ-1/Park7, and the $\alpha$ isoform of synuclein 
A
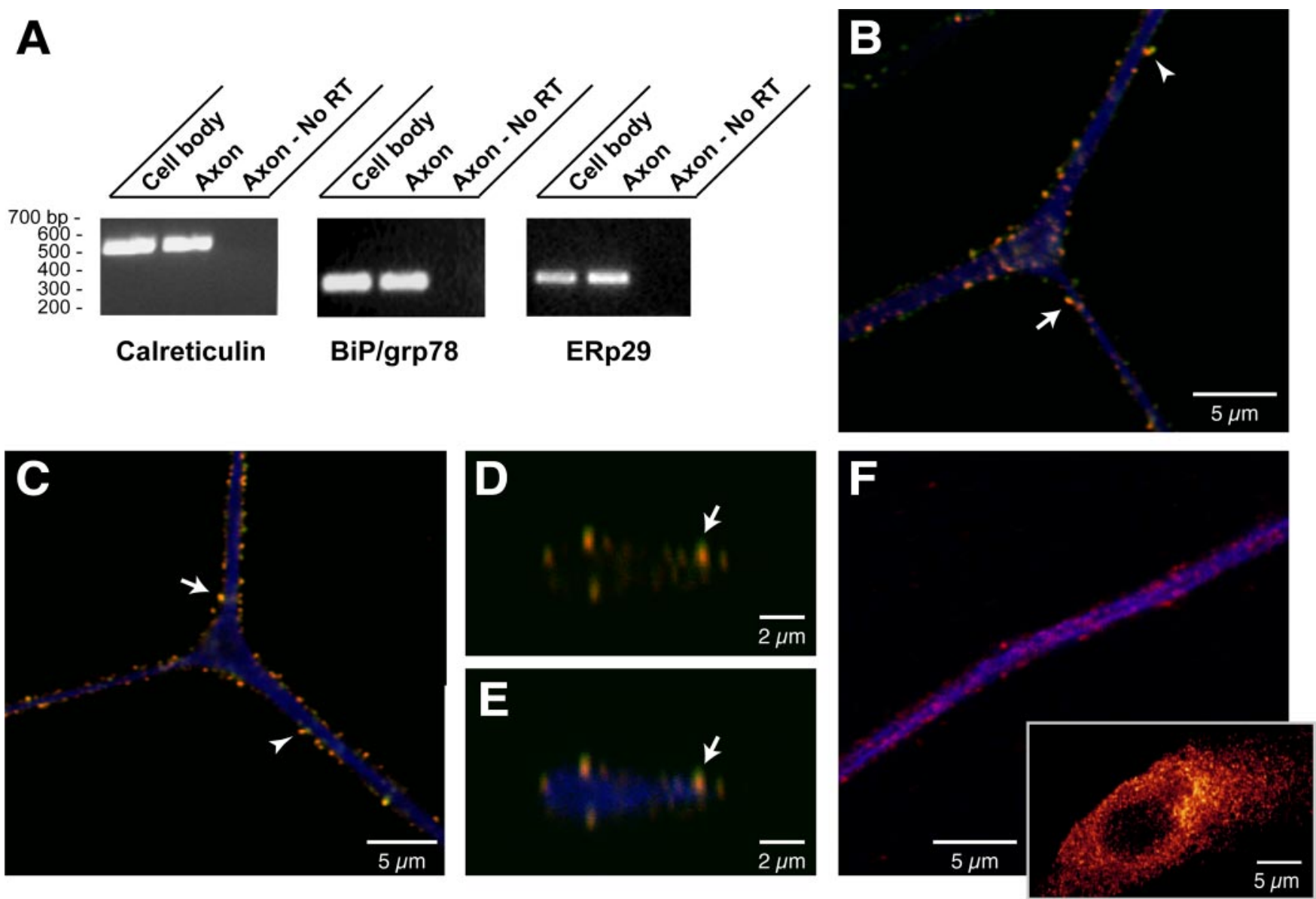

Figure 6. Resident-ER proteins and encoding mRNAs in DRG axons. A, RT-PCR for rat grp78/BiP, calreticulin, and ERp29 mRNAs shows that these transcripts extend into the DRG axons. Amplification of $\beta$ - and $\gamma$-actin mRNAs confirmed the absence of any $\gamma$-actin mRNA in the axonal sample. B, A single optical XY plane through the axon of a cultured DRG neuron showing calreticulin (green), SERCA (red), and neurofilament (blue) signals. The majority of calreticulin colocalizes with SERCA (arrow) with only occasional calreticulin signal seen in the absence of adjacent SERCA (arrowhead). C, A representative single optical XY plane through the axon of cultured DRG neurons stained for grp78/BiP (green), SERCA (red), and neurofilament (blue). Similar to calreticulin in B, the majority of grp78/BiP signal colocalizes with SERCA (arrow) and is rarely seen directly adjacent to SERCA-immunoreactive granules (arrowhead). D, E, A single XZ plane through the axon illustrated in ( taken at the bifurcation level. Signals for grp78/BiP (green) merged with SERCA (red) are shown in D, and grp78/Bip (green), Serca (red), and neurofilament (blue) are merged in $E$. Note that the grp78/BiP and SERCA immunoreactivity colocalize (arrows) and concentrate along the periphery of the axoplasm. F, A reconstructed three-dimensional confocal image of cultures stained for ERp29 and neurofilament is shown (14 optical XY planes taken at $\sim 0.12 \mu \mathrm{m}$ intervals). The panel shows a segment of distal axon with ERp29 in red and neurofilament in blue. The inset shows an adjacent Schwann cell with ERp29 channel intensity displayed as a spectrum, with yellow being the most intense. Similar to signals for calreticulin and grp78/BiP above, ERp29 immunoreactivity appears coarsely granular in the axon and is concentrated along the more peripheral extents of the neurofilament signal. The perinuclear concentration of ERp 29 in the $5 c h w a n n$ cells is characteristic of ER proteins.

have been detected in familial Parkinson's disease (Dauer and Przedborski, 2003). Mutations in SOD1 have been demonstrated in familial amyotrophic lateral sclerosis (Deng et al., 1993). Uch-L1 (also called PGP 9.5) has long been used as an in vivo marker for axons (Wilkinson et al., 1989), and by immunolabeling, Uch-L1 protein was concentrated in the growth cones of cultured DRG neurons (Fig. 7B). Staining of injury-conditioned DRG cultures for $\gamma$-synuclein, SP22, and SOD1 similarly showed that these locally synthesized proteins extended into the distal axon frequently concentrating in the growth cone (Fig. $7 C, D$ ). Signals for SP22 and SOD1 even appeared to extend into filopodia of large growth cones (Fig. 7D). The local synthesis of these proteins in axons may provide some insight into axonal pathology of Parkinson's disease and amyotrophic lateral sclerosis.

\section{Regulation of axonal mRNA localization by neurotrophins} The above studies show that the adult DRG neurons have the potential to synthesize several different proteins in their distal axons but do not address how or whether this axonal protein synthesis is regulated. Because NGF and BDNF increase neurite outgrowth in adult DRG cultures (Lindsay, 1988), we investigated the possibility that these neurotrophins might affect mRNA transport and, hence, the potential to locally produce new proteins in the DRG axons. For this, the axonal side of the DRGs cultured on membranes for $16 \mathrm{~h}$ was exposed to microparticles that had been absorbed with NGF or BDNF. BSA-absorbed microparticles were used as a control. The RNA polymerase II inhibitor DRB was included throughout the culture period to distinguish axonal localization of pre-existing mRNAs from any transcriptional regulation by these neurotrophins. DRB inhibits $>95 \%$ of new RNA synthesis in adult rat DRG cultures (Smith and Skene, 1997). Because axon number inherently varies between individual axonal preparations, the RNA isolates were normalized to protein content to provide equivalent axon mass between the treatment paradigms. Amplification of $12 \mathrm{~S}$ mitochondrial rRNA was further used as an internal control for reverse transcriptase efficiency. The $12 \mathrm{~S}$ mitochondrial rRNA amplifications showed little variation between the different treat- 

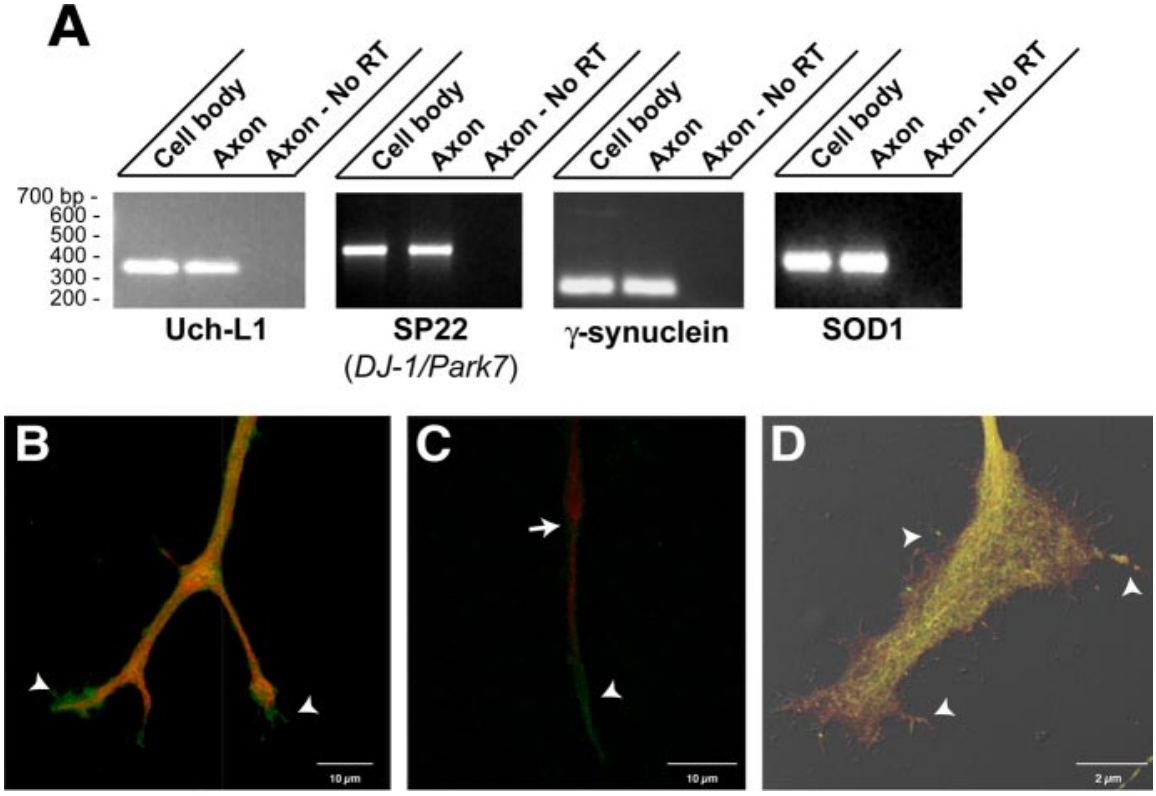

Figure 7. Neurodegeneration-associated proteins and encoding mRNAs extend into DRG axons. $A$, RNA isolated from cell-body versus axonal compartment was processed for RT-PCR using primers specific for Uch-L1, SP22, $\gamma$-synuclein, and SOD1 mRNAs. Each of these transcripts extends into the cultured DRG axons. Amplification of $\beta$-and $\gamma$-actin mRNAs confirmed the purity of the axonal RNA samples (data not shown). $B$, Image displays a three-dimensional projection through the distal axon of cultured DRG neurons that was reconstructed from $10 \mathrm{XY}$ optical planes taken over $3.5 \mu \mathrm{m}$ in the z-axis. Note that Uch-L1 immunoreactivity (green) extends beyond the neurofilament signal (red) into the growth cones of this branched axon (arrowheads). C, Image displays a three-dimensional projection through the distal axon of cultured DRG neurons stained for neurofilament (green) and $\gamma$-synuclein (red). Note that similar to Uch-L1, $\gamma$-synuclein also extends into the distal axon beyond the neurofilament (arrow). A prominent signal for $\gamma$-synuclein is also seen along the more proximal segments of the axon shaft (arrowhead). D, Image displays a three-dimensional projection of a growth cone from DRG cultures stained for SP22 (DJ-1/Park7) and SOD1. The SP22 (green) and SOD1 (red) signals represent a reconstruction of seven optical XY planes taken at $\sim 0.13 \mu \mathrm{m}$ intervals merged with the DIC image. Note that SP22 and SOD1 extend from axon shaft (arrow) into the growth cone and even into some of the filopodia (arrowheads).

ment conditions, and amplification of $\beta$-actin mRNA, but not $\gamma$-actin mRNA, confirmed the purity of the NGF-, BDNF-, and BSA-treated axonal preparations (Fig. $8 \mathrm{~A}$ ). Compared with the axonal levels of the $12 \mathrm{~S}$ mitochondrial rRNA, $\beta$-actin mRNA consistently increased with the more than $4 \mathrm{~h}$ NGF and BDNF treatment of the axons (Fig. $8 \mathrm{~A}$ ).

The Bassell group previously used bath-applied neurotrophins to show that neurotrophin 3 and BDNF increase axonal localization of $\beta$-actin mRNA in cortical neurons (Zhang et al., 1999; Zhang et al., 2001). Although our approach was to use local application of neurotrophins to the axons, any NGF or BDNF released from the microparticles in culture could freely diffuse to activate cell-body Trk receptors. To determine whether microparticle-absorbed neurotrophins were released into the medium over the course of the axonal treatments, we compared levels of phosphorylated TrkA NGF receptor in PC12 cells exposed to soluble NGF, NGF-absorbed microparticles, and supernatant from NGF-absorbed microparticles. The supernatant was prepared by incubating the NGF-absorbed microparticles in medium for $4 \mathrm{~h}$ under the same conditions as treatment of the axons above. Exposure to NGF-absorbed microparticles generated levels of phospho-TrkA ( $\operatorname{Trk}^{\mathrm{PY} 490}$ ) similar to concentrations of soluble NGF that completely saturate NGF receptors (Fig. $8 \mathrm{~B}$ ). No phospho-TrkA signal was detected in the PC12 cells treated with supernatant from the NGF-absorbed microparticles even when using 10-fold higher concentrations of those used in experiments outlined in Figure $8 \mathrm{~A}$. Although we cannot completely exclude all cell-body-derived effects of the neurotrophins, these data indicate that any neurotrophins released from the polystyrene mi- croparticles during the $4 \mathrm{~h}$ axonal treatments would be significantly diluted such that levels of Trk activation by these ligands are below our current limits of detection.

Real-time PCR was used to gain a quantitative assessment of axonal mRNA levels after local neurotrophin treatment. The majority of the axonal mRNAs showed no significant change with NGF or BDNF treatment compared with BSA control (Fig. 9) (supplemental Fig. S3, available at www.jneurosci.org as supplemental material). This argues that axonal localization of these mRNAs is not regulated by these growth-promoting stimuli. In contrast, axonal levels of $\beta$-actin, peripherin, and vimentin mRNAs increased by up to 4.5-fold with NGF and BDNF treatment above the BSA control (Fig. 9). Selective increase in transcription or half-lives of these cytoskeletal mRNAs after neurotrophin treatment could account for the increase in axonal levels of these transcripts. To address potential transcriptional changes, axons were locally treated with BSA- or NGF-coated microparticles and then RNA from cell body was analyzed by real-time RT-PCR. There was no significant change in $\beta$-actin, peripherin, or vimentin mRNA levels in the cell-body compartment (Fig. 9). To address potential changes in mRNA survival, axons were sheared from the cell bodies and then treated with BSA- or NGF-coated microparticles for 4 h. Quantitative RT-PCR showed no change in mRNA levels in the sheared axons comparing the NGF- to BSA-treated axon samples, indicating that neurotrophin-dependent changes in mRNA $t_{1 / 2}$ do not contribute to the selective increase in axonal $\beta$-actin, peripherin, and vimentin mRNAs after local treatment with neurotrophins. Together, these data indicate that local sources of neurotrophins increase transport of specific mRNAs from cell body into the axons. Chada and Hollenbeck (2003) recently showed that anterograde transport of mitochondria into axons is increased after similar local NGF treatment of embryonic chick DRG cultures. Thus, the normalization to axonal mitochondrial mRNAs that we used above may actually underestimate neurotrophin-induced change in mRNA transport.

\section{Discussion}

Even with compelling evidence that local translation contributes to the growth of both developing and regenerating axons (Campbell and Holt, 2001; Zhang et al., 2001; Zheng et al., 2001; Gallo et al., 2002; Ming et al., 2002), there have been few experimental means for an unbiased determination of what proteins axons synthesize. Most studies have been limited to identification of individual mRNAs or proteins. Recently, Moccia et al. (2003) reported 263 distinct mRNAs from Aplysia sensory axons, arguing that invertebrate axons have the potential to synthesize many different proteins. The proteomics approach used here shows that DRG axons can synthesize $>100$ distinctly migrating proteins by 2D gels. Resolution of proteins by $2 \mathrm{D}$ electrophoresis is limited by protein molecular weight, pI, and hydrophobicity ar- 
guing that the total number of axonally synthesized proteins is probably considerably larger. Although large $(\geq 75 \mathrm{kDa})$, small $(\leq 15 \mathrm{kDa})$, and hydrophobic proteins are not represented in our study, the MS identifications presented here substantially increase our knowledge of axonally synthesized proteins. Each of the proteins that we have identified may have a role in axonal growth, regeneration, and/or maintenance. The identification of these proteins by MS and the presence of their mRNAs in the axons strongly argue that they are indeed synthesized in the DRG axons.

\section{Synthesis of cytoskeletal proteins in regenerating axons}

The abundance of newly synthesized $\beta$-actin and tubulin proteins in our axonal preparation may be a reflection of the need for new cytoskeleton during axonal growth. Consistent with this notion, blocking axonal localization of $\beta$-actin mRNA in embryonic neurons causes axonal retraction (Zhang et al., 2001). Local synthesis of cofilin 1 in the regenerating DRG axons suggests that growing axons may also require local sources of actinbinding proteins. ADF, a protein with similar activities toward actin filaments (Bamburg, 1999), is locally synthesized in neonatal sympathetic axons (Lee and Hollenbeck, 2003). Both actin polymerizing and depolymerizing activities have been ascribed to these proteins (Bamburg, 1999; Ghosh et al., 2004). Thus, local generation of new cofilin in the DRG axons could alter microfilament dynamics. Axonally syn-

thesized $\gamma$-Tpm3 may similarly alter cytoskeletal dynamics, because tropomyosins appear to stabilize actin filaments (Bamburg, 1999). The localization of tropomyosin and cofilin proteins in growth cones is consistent with a role in growth (Bamburg and Bray, 1987; Letourneau and Shattuck, 1989; Schevzov et al., 1997).

The rat sensory axons also translate mRNAs encoding the intermediate filament proteins peripherin and vimentin. Our data are consistent with the well-established axonal localization of peripherin protein (Leonard et al., 1987, 1988), but further suggest that the protein can be locally synthesized in the axonal compartment. In myotubes, vimentin mRNA is localized to regions of vimentin assembly, suggesting that it is cotranslationally assembled into the cytoskeleton (Morris and Fulton, 1994). Cotranslational assembly of cytoskeleton in growing axons could provide a nidus for growth at points where axonal mRNAs are translated. Similar localization of tropomyosin mRNAs has been demonstrated in myoblasts, but apparently neither actin nor tubulin show evidence for such cotranslational assembly (Fulton and L'Ecuyer, 1993).

\section{Axonal synthesis of heat shock proteins}

Localized synthesis of HSP70 has been shown in presynaptic nerve terminals from squid optic lobe (Gioio et al., 2001; Jimenez
BSA NGF BDNF

\begin{tabular}{|l|l|l|l|l|}
\hline 30 & 35 & 25 & 30 & 35 \\
\hline
\end{tabular}

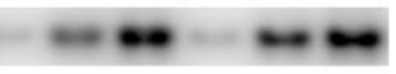

$\cdot$

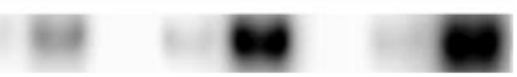

Beads BSA sup. NGF sup. (ng/mi)
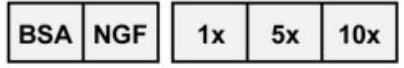

$1 x$

\begin{tabular}{|l|l|l|}
\hline$x$ & $5 x$ & $10 x$ \\
\hline
\end{tabular}
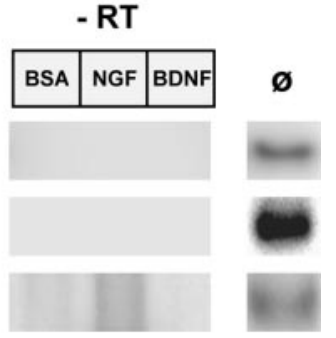

Figure 8. Local treatment with neurotrophins regulates axonal mRNA localization. $A$, The axonal compartments of DRG neuron cultures were selectively treated with NGF-, BDNF-, or BSA-absorbed microparticles for $4 \mathrm{~h}$ in the presence of the RNA synthesis

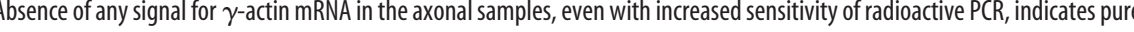
les compared with the BSA-treated axonal samples $B$, To determine whether significant levels of NGF were leached from the beads during the $4 \mathrm{~h}$ incubations shown in $A, P C 12$ cells were treated with soluble NGF $(0,10,50$, and $200 \mathrm{ng} / \mathrm{ml})$, BSA- or Fororbed beads, and supernatant (sup.) from BSA-or NGF-absorbed beads for $5 \mathrm{~min}$. The supernatant was used at onefold (1x), fivefold (5x), and 10-fold (10x) volume equivalents to the beads. The top panel shows activation of TrkA detected by

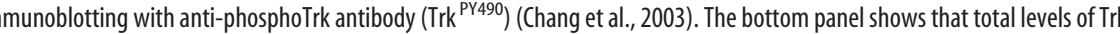
are relatively equivalent in all samples. Note that both soluble and bead-absorbed NGF activated TrkA, but the BSA-absorbed beads and supernatant from BSA- and NGF-absorbed beads showed no detectable phospho-TrkA.

et al., 2002), and the mRNA of Hsc70, a constitutively expressed HSP70 family member, has been detected in dendrites (Foster and Brown, 1996). Localized synthesis of other HSPs has not been reported previously. Several studies implicate HSPs as part of a generalized stress response. Induction of HSP mRNAs after thermal, ischemic, or traumatic injury of the nervous system has been demonstrated for several of the axonally synthesized HSPs that we have identified (Resendez et al., 1986; Lowenstein et al., 1991; Tedeschi and Ciavarra, 1997; Costigan et al., 1998; Liu et al., 1998; Yu et al., 1999; Mengesdorf et al., 2001; Hori et al., 2002). The HSPs are best characterized as molecular chaperones that can facilitate protein folding and formation of heteromolecular complexes and direct proteins to subcellular regions and organelles (Welch, 1992; Ohtsuka and Suzuki, 2000). Introduction of newly synthesized HSPs as well as the ER chaperone proteins may provide such chaperone functions to other axonally synthesized proteins. Alternatively, axonally synthesized HSPs may serve a cytoprotective function. Upregulation of HSPs increases resistance to subsequent thermal stress, excitotoxic insults, and trophic factor withdrawal (Lowenstein et al., 1991; Rordorf et al., 1991; Mailhos et al., 1993). Overexpression of neuronal HSP27 or HSP70 prevents excitotoxic and ischemic cell death, respectively (Kelly et al., 2002; Akbar et al., 2003; Kalwy et al., 2003), whereas suppression of neuronal grp78/BiP levels increases sensitivity to stress 

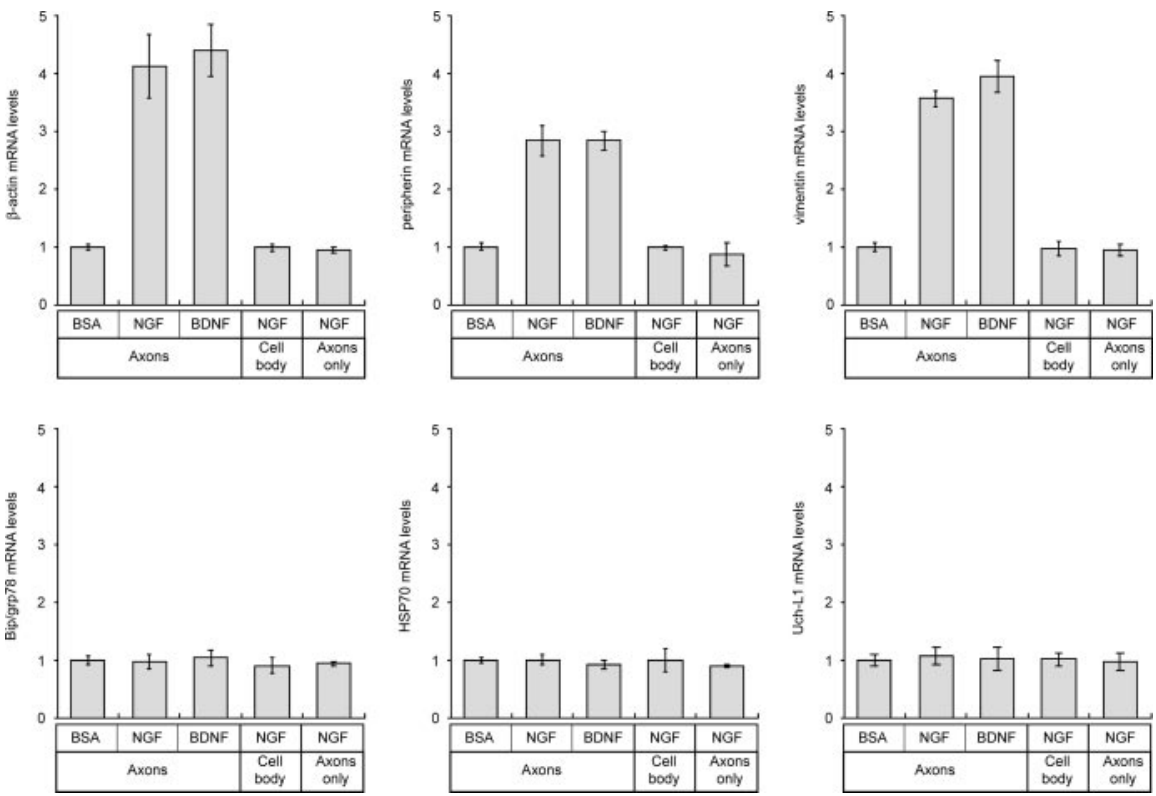

Figure 9. Neurotrophins regulate axonal localization of cytoskeletal protein mRNAs. Real-time RT-PCR was used to quantitate levels of specific mRNAs in the axonal RNA samples. Results for $\beta$-actin, peripherin, vimentin, grp78/BiP, HSP70, and Uch-L1 are illustrated. grp78/BiP, HSP70, and Uch-L1 signals are representative of transcripts that showed no change in levels after NGF or BDNF treatment (see supplemental Fig. S2, available at www.jneurosci.org as supplemental material). All values are displayed relative to a BSA-treated sample as a control. The top three panels represent cultures in which the axons were treated with microparticles, and axonal RNA was quantitated as in $A$. The bottom left panel represents values for cultures where axons were treated with microparticles as above, but the cell-body compartment was quantitated to evaluate potential changes in gene expression after neurotrophin treatment. The bottom center panel represents axonal RNA values in which axons isolated from the cell body were treated with microparticles and then RNAs were quantitated to evaluate potential neurotrophin-dependent changes in mRNA survival.

(Yu et al., 1999). Some chemotropic responses in developing $\mathrm{Xe}$ nopus retinal axons are mediated by local activation of apoptotic signaling pathways (Campbell and Holt, 2003). HSP27 appears to inhibit neuronal apoptosis after axotomy by preventing caspase-3 activation (Benn et al., 2002), and, in other cellular systems, HSPs have been argued to attenuate apoptotic signaling (Beere, 2004). Thus, in addition to protein folding and targeting, axonally synthesized HSPs may provide a means to locally restrict apoptotic signals. The anti-oxidant activities of SOD1, SP22 (DJ1/Park7), and peroxiredoxins 1 and 6 (Valentine and Hart, 2003; Wood et al., 2003; Taira et al., 2004) could similarly provide cytoprotective functions when locally generated in axons. It is important to note that we have detected synthesis of these injuryresponse and cytoprotective proteins in axons that have been separated from the cell body. Future studies will be needed to determine the extent of their synthesis in intact axons.

\section{ER proteins are synthesized in DRG axons}

Axonal synthesis of resident ER proteins raises the question of how newly synthesized proteins can be directed to organelles. The few ultrastructural examples of ribosomes in axons have not demonstrated any evidence for rough ER (Zelena, 1970, 1972; Peters et al., 1991; Bassell et al., 1998; Spencer et al., 2000; Zheng et al., 2001). Thus, it is not clear how or whether locally synthesized proteins could gain access to the ER. Previous studies have shown that axonally synthesized proteins can be targeted to the axonal membrane. Locally translated EphA2 mRNA is inserted into the growth cone membrane in developing axons (Brittis et al., 2002). Furthermore, microinjection of a G-protein-coupled receptor mRNA into snail axons results in ligand-responsive signaling (Spencer et al., 2000). Together with the vesicular localiza- tion of calreticulin, grp78/BiP, and ERp29 proteins in the DRG axons (Fig. 5), these data suggest that a functional equivalent of the rough ER and Golgi complex may indeed exist in the axonal compartment. Hess et al. (1999) provided evidence that functional Golgi contributes to axon growth, because inhibition of ADPribosylation factor, a protein involved in ER-Golgi and intra-Golgi transport, caused rapid retraction of growth cones.

\section{Intra-axonal synthesis of neurodegeneration-associated proteins} Local generation of Uch-L1, SP22 (DJ-1/ Park7), $\gamma$-synuclein, and SOD1 proteins in axons is an intriguing finding, because mutations in these proteins or their isoforms can lead to Parkinson's disease or amyotrophic lateral sclerosis (Deng et al., 1993; Dauer and Przedborski, 2003). Mice with nonsense mutations in Uch-L1 also show selective degeneration of sensory axons (Oda et al., 1992; Saigoh et al., 1999). As noted above, SP22 (DJ-1/Park7) and SOD1 have anti-oxidant activities (Valentine and Hart, 2003; Taira et al., 2004). Uch-L1 recycles ubiquitin from proteins targeted for degradation (Wilkinson et al., 1989), and overexpression of mouse $\gamma$-synuclein, persyn, leads to selective degradation of neurofilaments in cultured neurons (Buchman et al., 1998). Thus, Uch-L1 and $\gamma$-synuclein can play roles in proteolysis. Netrin-mediated growth cone turning in Xenopus axons requires activation of both local translation and proteolysis, but it is not clear what proteins are locally produced or degraded (Campbell and Holt, 2001). Intra-axonal synthesis of Uch-L1 and $\gamma$-synuclein may effectively link axonal protein synthesis and proteolysis. Locally generated ER chaperone proteins could also contribute to axonal proteolysis as part of the unfolded protein response (Kostova and Wolf, 2003).

\section{Regulation of axonal mRNA localization}

Altering the transport of mRNAs into the axons is one means to regulate local protein synthesis. Bath application of neurotrophins increases $\beta$-actin mRNA localization in embryonic cortical axons (Zhang et al., 1999). Our data indicate that local sources of NGF and BDNF selectively increase transport of $\beta$-actin, peripherin, and vimentin mRNAs from cell body into the axons. Surprisingly, the majority of the axonal mRNAs did not show any detectable alterations after neurotrophin treatment. Although our studies are limited to growth-promoting stimuli, this may indicate that some mRNAs are constitutively transported into the axons. Identification of ribosome constituents in uninjured axons argues that mature, nongrowing axons would have the means to use such mRNAs (Koenig et al., 2000). Because many of the nonregulated axonal mRNAs in our system encode proteins upregulated by cellular stress, constitutive axonal localization of mRNAs may provide a means to locally respond to axonal injury. Cap-independent translation of HSP mRNAs has been suggested in other cellular systems (Macejak and Sarnow, 1991; Joshi-Barve et al., 1992), and this could provide a means to activate translation of selective axonal mRNAs. Recent work by Hanz et al. 
(2003) supports the notion of translational control by axonal injury, because axonal crush injury induces de novo synthesis of axonal Importin- $\beta 1$.

\section{References}

Akbar M, Lundberg A, Liu K, Vidyadaran S, Wells K, Dolatshad H, Wynn S, Wells D, Latchman D, de Belleroche J (2003) The neuroprotective effects of heat shock protein 27 overexpression in transgenic animals against kainate-induced seizures and hippocampal cell death. J Biol Chem 278:19956-19965.

Aronov S, Aranda G, Behar L, Ginzburg I (2001) Axonal tau mRNA localization coincides with tau protein in living neuronal cells and depends on axonal targeting signal. J Neurosci 21:6577-6587.

Bamburg JR (1999) Proteins of the ADF/cofilin family: essential regulators of actin dynamics. Annu Rev Cell Dev Biol 15:185-230.

Bamburg JR, Bray D (1987) Distribution and cellular localization of actin depolymerizing factor. J Cell Biol 105:2817-2825.

Bassell GJ, Zhang H, Byrd AL, Femino AM, Singer RH, Taneja KL, Lifshitz LM, Herman IM, Kosik KS (1998) Sorting of beta-actin mRNA and protein to neurites and growth cones in culture. J Neurosci 18:251-265.

Beere HM (2004) "The stress of dying": the role of heat shock proteins in the regulation of apoptosis. J Cell Sci 117:2641-2651.

Benn SC, Perrelet D, Kato AC, Scholz J, Decosterd I, Mannion RJ, Bakowska JC, Woolf CJ (2002) Hsp27 upregulation and phosphorylation is required for injured sensory and motor neuron survival. Neuron 36:45-56.

Brittis PA, Lu Q, Flanagan JG (2002) Axonal protein synthesis provides a mechanism for localized regulation at an intermediate target. Cell 110:223-235.

Buchman VL, Adu J, Pinon LG, Ninkina NN, Davies AM (1998) Persyn, a member of the synuclein family, influences neurofilament network integrity. Nat Neurosci 1:101-103.

Campbell D, Holt C (2001) Chemotropic responses of retinal growth cones mediated by rapid local protein synthesis and degradation. Neuron 32:1013-1016.

Campbell DS, Holt CE (2003) Apoptotic pathway and MAPKs differentially regulate chemotropic responses of retinal growth cones. Neuron 37:939-952.

Capano CP, Giuditta A, Castigli E, Kaplan B (1987) Occurrence and complexity of polyadenylated RNA in squid axoplasm. J Neurochem 49:698-704.

Chada SR, Hollenbeck PJ (2003) Mitochondrial movement and positioning in axons: the role of growth factor signaling. J Exp Biol 206:1985-1992.

Chang JH, Mellon E, Schanen NC, Twiss JL (2003) Persistent TrkA activity is necessary to maintain transcription in neuronally differentiated PC12 cells. J Biol Chem 278:42877-42885.

Chromozinski P, Sacchi N (1987) Single-step method of RNA isolation by guanidine isothiocyanate-phenol-chloroform extraction. Anal Biochem 162:156-159.

Chun J-T, Gioio A, Crispino M, Capano C, Giuditta A, Kaplan B (1996) Differential compartmentalization of mRNAs in squid giant axon. J Neurochem 67:1806-1812.

Cochard P, Paulin D (1984) Initial expression of neurofilaments and vimentin in the central and peripheral nervous system of the mouse embryo in vivo. J Neurosci 4:2080-2094.

Colucci-Guyon E, Portier MM, Dunia I, Paulin D, Pournin S, Babinet C (1994) Mice lacking vimentin develop and reproduce without an obvious phenotype. Cell 79:679-694.

Costigan M, Mannion RJ, Kendall G, Lewis SE, Campagna JA, Coggeshall RE, Meridith-Middleton J, Tate S, Woolf CJ (1998) Heat shock protein 27: developmental regulation and expression after peripheral nerve injury. J Neurosci 18:5891-5900.

Dauer W, Przedborski S (2003) Parkinson's disease: mechanisms and models. Neuron 39:889-909.

Davis L, Dou P, DeWit M, Kater S (1992) Protein synthesis within neuronal growth cones. J Neurosci 12:4867-4877.

Deng HX, Hentati A, Tainer JA, Iqbal Z, Cayabyab A, Hung WY, Getzoff ED, Hu P, Herzfeldt B, Roos RP, Warner C, Deng G, Soriano E, Smyth C, Parge HE, Ahmed A, Roses AD, Hallewell RA, Pericak-Vance MA, Siddique T (1993) Amyotrophic lateral sclerosis and structural defects in $\mathrm{Cu}, \mathrm{Zn}$ superoxide dismutase. Science 261:1047-1051.

Eng H, Lund K, Campenot RB (1999) Synthesis of beta-tubulin, actin, and other proteins in axons of sympathetic neurons in compartmented cultures. J Neurosci 19:1-9.

Foster J, Brown I (1996) Intracellular localization of heat shock mRNAs (hsc70 and hsp70) to neuronal cell bodies and processes in the control and hyperthermic rabbit brain. J Neurosci Res 46:652-665.

Fulton A, L'Ecuyer T (1993) Cotranslational assembly of some cytoskeletal proteins: implications and prospects. J Cell Sci 105:867-871.

Gallo G, Ernst A, McLoon S, Letourneau P (2002) Transient PKA activity is required for initiation but not maintenance of BDNF-mediated protection from nitric oxide-induced growth-cone collapse. J Neurosci 22:5016-5023.

Garner C, Tucker R, Matus A (1988) Selective localization of messenger RNA for MAP2 in dendrites. Nature 336:674-677.

Ghosh M, Song X, Mouneimne G, Sidani M, Lawrence DS, Condeelis JS (2004) Cofilin promotes actin polymerization and defines the direction of cell motility. Science 304:743-746.

Gioio AE, Eyman M, Zhang H, Scotto Lavina Z, Giuditta A, Kaplan BB (2001) Local synthesis of nuclear-encoded mitochondrial proteins in the presynaptic terminal. J Neurosci Res 64:447-453.

Giuditta A, Menichini E, Capano CP, Langella M, Martin R, Castigli E, Kaplan B (1991) Active polysomes in the axoplasm of the squid giant axon. J Neurosci Res 28:21-28.

Gunning P, Weinberger R, Jeffrey P (1997) Actin and tropomyosin isoforms in morphogenesis. Anat Embryol (Berl) 195:311-315.

Hannan AJ, Schevzov G, Gunning P, Jeffrey PL, Weinberger RP (1995) Intracellular localization of tropomyosin mRNA and protein is associated with development of neuronal polarity. Mol Cell Neurosci 6:397-412.

Hannan AJ, Gunning P, Jeffrey PL, Weinberger RP (1998) Structural compartments within neurons: developmentally regulated organization of microfilament isoform mRNA and protein. Mol Cell Neurosci 11:289-304.

Hanz S, Perlson E, Willis D, Zheng JQ, Massarwa R, Huerta JJ, Koltzenburg M, Kohler M, van-Minnen J, Twiss JL, Fainzilber M (2003) Axoplasmic importins enable retrograde injury signaling in lesioned nerve. Neuron 40:1095-1104.

Hess DT, Smith DS, Patterson SI, Kahn RA, Skene JH, Norden JJ (1999) Rapid arrest of axon elongation by brefeldin A: a role for the small GTPbinding protein ARF in neuronal growth cones. J Neurobiol 38:105-115.

Hori O, Ichinoda F, Tamatani T, Yamaguchi A, Sato N, Ozawa K, Kitao Y, Miyazaki M, Harding HP, Ron D, Tohyama M, Stern DM, Ogawa S (2002) Transmission of cell stress from endoplasmic reticulum to mitochondria: enhanced expression of Lon protease. J Cell Biol 157:1151-1160.

Jimenez CR, Eyman M, Lavina ZS, Gioio A, Li KW, van der Schors RC, Geraerts WP, Giuditta A, Kaplan BB, van Minnen J (2002) Protein synthesis in synaptosomes: a proteomics analysis. J Neurochem 81:735-744.

Joshi-Barve S, de Benedetti A, Rhoads R (1992) Preferential translation of heat shock mRNAs in HeLa cells deficient in protein synthesis initiation factors eIF4E and eIF4 $\gamma^{*}$. J Biol Chem 267:21038-21043.

Kalwy S, MT A, Coffin R, de Belleroche J, Latchman D (2003) Heat shock protein 27 delivered via a herpes simplex virus vector can protect neurons of the hippocampus against kainic-acid-induced cell loss. Brain Res Mol Brain Res 111:91-103.

Kelly S, Zhang ZJ, Zhao H, Xu L, Giffard RG, Sapolsky RM, Yenari MA, Steinberg GK (2002) Gene transfer of HSP72 protects cornu ammonis 1 region of the hippocampus neurons from global ischemia: influence of Bcl-2. Ann Neurol 52:160-167.

Koenig E (1989) Cycloheximide-sensitive $\left[{ }^{35} \mathrm{~S}\right]$ methionine labeling of proteins in goldfish retinal ganglion cell axons in vitro. Brain Res 481:119-123.

Koenig E, Martin R, Titmus M, Sotelo-Silveira JR (2000) Cryptic peripheral ribosomal domains distributed intermittently along mammalian myelinated axons. J Neurosci 20:8390-8400.

Kostova Z, Wolf DH (2003) For whom the bell tolls: protein quality control of the endoplasmic reticulum and the ubiquitin-proteasome connection. EMBO J 22:2309-2317.

Lee S, Hollenbeck P (2003) Organization and translation of mRNA in sympathetic axons. J Cell Sci 116:4467-4478.

Leonard DG, Ziff EB, Greene LA (1987) Identification and characterization of mRNAs regulated by nerve growth factor in PC12 cells. Mol Cell Biol 7:3156-3167.

Leonard DG, Gorham JD, Cole P, Greene LA, Ziff EB (1988) A nerve growth 
factor-regulated messenger RNA encodes a new intermediate filament protein. J Cell Biol 106:181-193.

Letourneau PC, Shattuck TA (1989) Distribution and possible interactions of actin-associated proteins and cell adhesion molecules of nerve growth cones. Development 105:505-519.

Li KW, Geraerts WP, van Elk R, Joosse J (1989) Quantification of proteins in the subnanogram and nanogram range: comparison of the AuroDye, FerriDye, and India ink staining methods. Anal Biochem 182:44-47.

Li KW, Hornshaw MP, Van Der Schors RC, Watson R, Tate S, Casetta B, Jimenez CR, Gouwenberg Y, Gundelfinger ED, Smalla KH, Smit AB (2004) Proteomics analysis of rat brain postsynaptic density: implications of the diverse protein functional groups for the integration of synaptic physiology. J Biol Chem 279:987-1002.

Lindsay R (1988) Nerve growth factors (NGF, BDNF) enhance axonal regeneration but are not required for survival of adult sensory neurons. J Neurosci 8:2394-2405.

Liu H, Miller E, van de Water B, Stevens J (1998) Endoplasmic reticulum stress proteins block oxidant-induced $\mathrm{Ca}^{2+}$ increases and cell death. J Biol Chem 273:12858-12862.

Lowenstein DH, Chan PH, Miles MF (1991) The stress protein response in cultured neurons: characterization and evidence for a protective role in excitotoxicity. Neuron 7:1053-1060.

Macejak D, Sarnow P (1991) Internal initiation of translation mediated by the 5' leader of a cellular mRNA. Nature 353:90-94.

Mailhos C, Howard MK, Latchman DS (1993) Heat shock protects neuronal cells from programmed cell death by apoptosis. Neuroscience 55:621-627.

Mengesdorf T, Althausen S, Oberndorfer I, Paschen W (2001) Response of neurons to an irreversible inhibition of endoplasmic reticulum $\mathrm{Ca}^{2+}$. ATPase: relationship between global protein synthesis and expression and translation of individual genes. Biochem J 356:805-815.

Ming GL, Wong ST, Henley J, Yuan XB, Song HJ, Spitzer NC, Poo MM (2002) Adaptation in the chemotactic guidance of nerve growth cones. Nature 417:411-418.

Moccia R, Chen D, Lyles V, Kapuya E, Estreya Y, Yaping E, Kalachikov S, Spahn CM, Frank J, Kandel ER, Barad M, Martin KC (2003) An unbiased cDNA library prepared from isolated Aplysia sensory neuron processes is enriched for cytoskeletal and translational mRNAs. J Neurosci 23:9409-9417.

Molliver DC, Radeke MJ, Feinstein SC, Snider WD (1995) Presence or absence of TrkA protein distinguishes subsets of small sensory neurons with unique cytochemical characteristics and dorsal horn projections. J Comp Neurol 361:404-416.

Morris EJ, Fulton AB (1994) Rearrangement of mRNAs for costamere proteins during costamere development in cultured skeletal muscle from chicken. J Cell Sci 107:377-386.

Oda K, Yamazaki K, Miura H, Shibasaki H, Kikuchi T (1992) Dying back type axonal degeneration of sensory nerve terminals in muscle spindles of the gracile axonal dystrophy (GAD) mutant mouse. Neuropathol Appl Neurobiol 18:265-281.

Ohtsuka K, Suzuki T (2000) Roles of molecular chaperone proteins in the nervous system. Brain Res Bull 53:141-146.

Olink-Coux M, Hollenbeck PJ (1996) Localization and active transport of mRNA in axons of sympathetic neurons in culture. J Neurosci 16:1346-1358.

Peters A, Palay S, Webster H (1991) The fine structure of the nervous system, Ed 3, pp 101-137. New York: Oxford UP.

Piper M, Holt C (2004) RNA translation in axons. Annu Rev Cell Dev Biol 20:505-523.

Pratt WB, Toft DO (2003) Regulation of signaling protein function and trafficking by the hsp90/hsp70-based chaperone machinery. Exp Biol Med (Maywood) 228:111-133.

Resendez Jr E, Ting J, Kim KS, Wooden SK, Lee AS (1986) Calcium ionophore A23187 as a regulator of gene expression in mammalian cells. J Cell Biol 103:2145-2152.

Rordorf G, Koroshetz WJ, Bonventre JV (1991) Heat shock protects cultured neurons from glutamate toxicity. Neuron 7:1043-1051.

Saigoh K, Wang YL, Suh JG, Yamanishi T, Sakai Y, Kiyosawa H, Harada T, Ichihara N, Wakana S, Kikuchi T, Wada K (1999) Intragenic deletion in the gene encoding ubiquitin carboxy-terminal hydrolase in gad mice. Nat Genet 23:47-51.

Schevzov G, Gunning P, Jeffrey PL, Temm-Grove C, Helfman DM, Lin JJ, Weinberger RP (1997) Tropomyosin localization reveals distinct populations of microfilaments in neurites and growth cones. Mol Cell Neurosci 8:439-454.

Shaw G, Banker GA, Weber K (1985) An immunofluorescence study of neurofilament protein expression by developing hippocampal neurons in tissue culture. Eur J Cell Biol 39:205-216.

Smith DS, Skene P (1997) A transcription-dependent switch controls competence of adult neurons for distinct modes of axon growth. J Neurosci 17:646-658.

Spencer GE, Syed NI, van Kesteren E, Lukowiak K, Geraerts WP, van Minnen J (2000) Synthesis and functional integration of a neurotransmitter receptor in isolated invertebrate axons. J Neurobiol 44:72-81.

Steward O (2002) mRNA at synapses, synaptic plasticity, and memory consolidation. Neuron 36:338-340.

Taira T, Saito Y, Niki T, Iguchi-Ariga SM, Takahashi K, Ariga H (2004) DJ-1 has a role in antioxidative stress to prevent cell death. EMBO Rep 5:430.

Tapscott SJ, Bennett GS, Toyama Y, Kleinbart F, Holtzer H (1981) Intermediate filament proteins in the developing chick spinal cord. Dev Biol 86:40-54.

Tedeschi B, Ciavarra RP (1997) Differential effects of axotomy on the in vivo synthesis of the stress-inducible and constitutive 70-kDa heat-shock proteins in rat dorsal root ganglia. Brain Res Mol Brain Res 45:199-206.

Treiman M (2002) Regulation of endoplasmic reticulum calcium storage during the unfolded protein response-significance in tissue ischemia. Trends Cardiovasc Med 12:57-62.

Twiss JL, Smith DS, Chang B, Shooter EM (2000) Translational control of ribosomal protein L4 is required for rapid neurite extension. Neurobiol Dis 7:416-428.

Valentine JS, Hart PJ (2003) Misfolded CuZnSOD and amyotrophic lateral sclerosis. Proc Natl Acad Sci USA 100:3617-3622.

van Minnen J, Bergman J, Kesteren EV, Smit A, Geraerts W, Lukowiak K, Hasan S, Syed N (1997) De novo protein synthesis in isolated axons of identified neurons. Neuroscience 80:1-7.

Weinberger RP, Henke RC, Tolhurst O, Jeffrey PL, Gunning P (1993) Induction of neuron-specific tropomyosin mRNAs by nerve growth factor is dependent on morphological differentiation. J Cell Biol 120:205-215.

Welch WJ (1992) Mammalian stress response: cell physiology, structure/ function of stress proteins, and implications for medicine and disease. Physiol Rev 72:1063-1081.

Wilkinson KD, Lee KM, Deshpande S, Duerksen-Hughes P, Boss JM, Pohl J (1989) The neuron-specific protein PGP 9.5 is a ubiquitin carboxylterminal hydrolase. Science 246:670-673.

Wood ZA, Schroder E, Robin Harris J, Poole LB (2003) Structure, mechanism and regulation of peroxiredoxins. Trends Biochem Sci 28:32-40.

Yu LR, Conrads TP, Uo T, Kinoshita Y, Morrison RS, Lucas DA, Chan KC, Blonder J, Issaq HJ, Veenstra TD (2004) Global analysis of the cortical neuron proteome. Mol Cell Proteomics 3:896-907.

Yu Z, Luo H, Fu W, Mattson M (1999) The endoplasmic reticulum stressresponsive protein GRP78 protects neurons against exitotoxicity and apoptosis: suppression of oxidative stress and stabilization of calcium homeostasis. Exp Neurol 155:302-314.

Zelena J (1970) Ribosome-like particles in myelinated axons of the rat. Brain Res 24:359-363.

Zelena J (1972) Ribosomes in myelinated axons of dorsal root ganglia. Zeitschrift fur Zellforschung und Mikroskopische Anatomie 124:217-229.

Zhang HL, Singer RH, Bassell GJ (1999) Neurotrophin regulation of betaactin mRNA and protein localization within growth cones. J Cell Biol 147:59-70.

Zhang HL, Eom T, Oleynikov Y, Shenoy SM, Liebelt DA, Dictenberg JB, Singer RH, Bassell GJ (2001) Neurotrophin-induced transport of a betaactin mRNP complex increases beta-actin levels and stimulates growth cone motility. Neuron 31:261-275.

Zheng J-Q, Kelly T, Chang B, Ryazantsev S, Rajasekaran A, Martin K, Twiss JL (2001) A functional role for intra-axonal protein synthesis during axonal regeneration from adult sensory neurons. J Neurosci 21:9291-9303. 